\title{
37. SEDIMENTOLOGIC SUMMARY, NANKAI TROUGH SITES 582 AND 583, AND JAPAN TRENCH SITE 584 1
}

\author{
William T. Coulbourn, Hawaii Institute of Geophysics, University of Hawaii ${ }^{2}$
}

\begin{abstract}
Hemipelagic olive gray mud blankets both areas drilled during DSDP Leg 87 of the Glomar Challenger. This sedimentary facies is typical of the accumulation blanketing the landward slope of most active margins and was predicted prior to the expedition. It is the properties of and structures within this sediment and whatever facies that might underlie it that are of special interest at convergent plate boundaries. At Site 582 in the Nankai Trough, hemipelagic and turbiditic olive gray muds overlie muds of nearly the same color that accumulated in the Shikoku Basin to the southeast. A change in trace fossil assemblages, increase in calcium carbonate content, and decrease in porosity distinguish the two lithologic units present at Site 582. Sands are present throughout the trench-fill sequence but are underrepresented due to loss in the coring process. All microfossil groups are poorly represented throughout. The fine structure of these abyssal sediments is revealed in hydraulic piston cores taken at four locations at Site 583 on the landward slope. Graded beds dip steeply seaward at two of these Site 583 holes but are nearly horizontal at the other two. Authigenic carbonates have precipitated in the coarser, basal layers, forming aggregates up to $5 \mathrm{~cm}$ across.

The hemipelagic muds accumulated at Site 584 on the 4000 -m-deep terrace northeast of Honshu are uniform throughout the $940 \mathrm{~m}$ penetrated. This stable depositional environment was interrupted by sporadic turbidity flows that left mud turbidites in the Miocene portion of the lithologic section. These deposits are grayer than the olive gray matrix that envelopes them. Bedding dips are generally seaward and increase to 60 to $70^{\circ}$ in the deeper cores from Hole 584 . An otherwise monotonous sedimentary section is rendered fascinating by its wealth of small-scale structure. Dewatering veinlets, healed offsets, and pull-apart structures abound. Bioturbation is prominent throughout most of the cores, but trace fossils become particularly abundant and diverse in the lower Miocene portion. Diatom abundance decreases downhole, but biostratigraphic control is good throughout-the oldest sediment recovered is lowermost middle Miocene. The sedimentary facies represents a deep-water environment of deposition throughout the interval cored. If the basal undrillable horizon at Site 584 is the upper surface of a foundered Oyashio landmass, that terrane had subsided to bathyal depths by middle-early Miocene time.
\end{abstract}

\section{INTRODUCTION}

Processes governing the evolution of convergent margins are probably as poorly understood as those of any tectonic setting on the surface of the Earth. Unlike passive continental margins and continental borderlands, active continental margins are not yet prime targets for hydrocarbon exploration, perhaps because of their lower economic potential, greater water depths, and complexity of structure. Geophysical investigations have outlined the vectors for lithospheric convergence, and seismic reflection profiling has rendered broadly averaged images of the surface and sub-bottom structure. Processes governing sedimentation in and along active margins, especially in the forearc regions, are a subject of controversy, because of a scarcity of subaerial exposures such as Nias, Barbados, and the Makran (Moore et al., 1980; Speed, 1981; White and Louden, 1982; Saunders et al., 1984), and a reliance on geophysical methods for surveying the submarine setting. Only recently has the technology become available to produce images of the wealth of detail present in the morphology of the active-margin seafloor (e.g., Renard et al., 1980; Aubouin, Stephan, et al., 1982; Stride et al., 1982; Belderson et al., 1984; Fon-

\footnotetext{
${ }^{1}$ Kagami, H., Karig, D. E., Coulbourn, W. T., et al., Init. Repts, DSDP, 87: Washington (U.S. Govt. Printing Office).

2 Address: Hawaii Institute of Geophysics, University of Hawaii, 2525 Correa Road, Honolulu, Hawaii 96822.
}

tas et al., 1984). If relatively little is known about the details of the submarine structure, even less is known about the sediment and rock caught in this setting. Great water depth, irregular bathymetry, complicated structure, and variable and localized outcrops complicate conventional sampling methods. Twelve voyages of the Glomar Challenger were dedicated at least in part to sampling convergent margins (see fig. 3 of Introduction, this volume), but even the most sophisticated technology available on this drill ship has afforded only partial success in this difficult terrane. Despite brecciated formations, poor sample recovery, caving holes, stuck drill strings, gas-bearing formations, and more than one typhoon, these expeditions have succeeded in providing a measure of "ground-truth," which serves as a foundation for evaluating the quality and scale of information provided by indirect survey techniques.

The lithologic sequences recovered in DSDP samples and in regional sedimentological investigations based on piston and gravity cores demonstrate that most active margins of the world are blanketed by an apron of cohesive olive gray, hemipelagic to terrigenous silt and clay with varying amounts of diatoms and glass shards (e.g., Zen, 1959; Connolly and Ewing, 1967; Damuth, 1980; McMillen and Haines, 1982; McMillen et al., 1982; Coulbourn, 1981; Coulbourn et al., 1982; and fig. 3 of the Introduction, this volume). Only indirectly related to the subduction process, this dark gray green, hemipelagic sediment reflects the position of many active margins 
beneath zones of upwelling and highly productive surface waters. Carbonate-rich sediments are poorly represented. The calcite compensation depth (CCD) shoals toward the periphery of ocean basins (Berger and Winterer, 1974; Berger et al., 1976), so that unless they are rapidly buried, calcareous microfossils are dissolved in the water column or on the seafloor. Those assemblages present in water depths greater than $2500 \mathrm{~m}$ are suspect, because of the effects of partial solution and reworking (Coulbourn, 1981). One unexpected aspect of the DSDP results is the realization that this drape of olive gray (5Y $3 / 2$ on Munsell's code) slope sediment is usually very thick. In general, the experience of DSDP active margin drilling is one of a repeated failure to sample an "accretionary prism" predicted from the geometry of seismic reflectors (Talwani and Langseth, 1981; fig. 2 of Hussong et al., 1982b, and fig. 13 of von Huene et al., 1982). Instead, drilling has recovered $1 \mathrm{~km}$ or more of slope sediment from most active margins. After a decade of exploration, confirmation of the "trench-slope model" (Seely et al., 1974) remains elusive, particularly for its type-area offshore of Guatemala (Aubouin, von Huene et al., 1982a, 1982b). The imbricate structures are probably formed by the in-place deformation of slope deposits (Scholl et al., 1977) blanketing a tectonically eroding substrate (see fig. 6 , Introduction, this volume). In contrast to the scarcity of confirmed accretionary prisms in modern subduction zones, several exposed belts of deformed sedimentary rocks are assigned to ancient forearc settings (Hamilton, 1969; Moore, 1973; Leggett, 1980; Seiders, 1983; MacKinnon, 1983; also, see Aubouin and Blanchet, 1981, for discussion and list of examples).

Irrespective of how the process occurs, sediment is subducted along the most "accretionary" of convergent plate boundaries, margins like the Nankai. For example, east of the Lesser Antilles, the lower two-thirds of the sediment column of the Atlantic Plate is passing beneath the seaward part of the Barbados accretionary complex (Westbrook et al., 1982). In the Makran, about $2.5 \mathrm{~km}$ of sediment becomes involved in the deforming margin, whereas the lower 3 to $4 \mathrm{~km}$ appears to ride passively with the Arabian Plate down into the subduction zone (White and Louden, 1982). The part of the sedimentary column that stays up is split along a décollement from the portion that goes down. Aspects of the sediment that control the position of the décollement are unknown, but pore-water pressure is probably crucial (Westbrook and Smith, 1983; Bray and Karig, this volume).

The nature of the rock and sediment underlying the slope apron is also unknown for most margins. The Guatemalan margin is a notable exception. Two months of drilling were required during Leg 67 (Aubouin, von Huene, et al., 1982a), followed by two years of assessment of those results and a second expedition (Leg 84) to that segment of the Middle America Trench, before the underlying ophiolitic complex was uncovered (Aubouin, von Huene, et al., 1982b). Other unknowns include: the relative importance of gravitational and tectonic processes, the manner of growth and form of deep-sea sediment fans, and the structures in and physical properties of the sediment on active margins.

The Nankai Trough and the Japan Trench are particularly suitable locales to pursue these investigations. Although seafloor images were not available at the time of the cruise, the bathymetry of each region is well known. Both areas were drilled during previous Glomar Challenger voyages, and presite surveys have produced a suite of processed seismic reflection profiles (Figs. 1 and 2; and Nasu et al., 1979, 1982).

\section{NANKAI TROUGH-LEG 87A}

\section{Geologic Setting}

The Nankai Trough is unusual among subduction zones of the world. A Wadati-Benioff zone, typical of most active margins, is limited to less than $150 \mathrm{~km}$ in the Nankai region (Kanamori and Tsumura, 1971; Aoki et al., 1982). Heat flow is abnormally high; and the trenchlike depression is much reduced (Fig. 3). Offshore of Shiko$\mathrm{ku}$ Island and the Tosa Basin, the seaward flank of the trench is marked only by a very low outer swell, the southwestward prolongation of the trend of the Zenisu Ridge (Fig. 3). The Trough itself is shallow compared to most trenches; depths range between 4000 and $4800 \mathrm{~m}$, only several hundred meters deeper than the Shikoku Basin. On Shikoku, a belt of folded and faulted sedimentary rocks, the Shimanto subgroup, is exposed subaerially. These outcrops include sandstones and mudstones, which in places incorporate basaltic pillow lavas and radiolarian cherts (Taira, 1981; Taira et al., 1982).

In other respects the Nankai Trough is representative of subduction zones in general. The subducted ocean crust can be traced about $60 \mathrm{~km}$ landward of the Nankai Trough on some processed multichannel seismic profiles (Nasu et al., 1982; Aoki et al., 1982). A décollement near the base of the turbidite sequence is the tectonic contact between the two lithospheric plates. The subhorizontal reflectors beneath represent the Shikoku Basin sediment, which is riding into the subduction zone at a rate of between 2 and $5 \mathrm{~cm} / \mathrm{yr}$. (Fitch and Scholz, 1971; Karig, Ingle, et al., 1975; Seno, 1977). Because the sedimentary column is thick, the Nankai resembles sediment-choked active margins like Barbados (Moore, Biju-Duval, et al., 1984) and the Makran (White and Louden, 1982). As is common in this setting, a series of ridges emerges along thrusts rooted in the basal detachment beneath the landward slope. Although each ridge ponds different amounts of sediment (Hilde et al., 1968), accumulations generally increase in thickness upslope as the spacing between ridges increases (Aoki et al., 1982). The Muroto, Tosa, and Hyuga basins are terraces in the bathymetric sense (Ludwig et al., 1973) but are basins in a structural sense; accumulations in the Tosa Basin alone reach $4.0 \mathrm{~km}$ thickness (Yoshii et al., 1973).

Bottom-simulating reflectors (BSRs) are recorded on some of the multichannel seismic profiles seaward of Shikoku Island and to the northeast of the Leg 87A tran- 


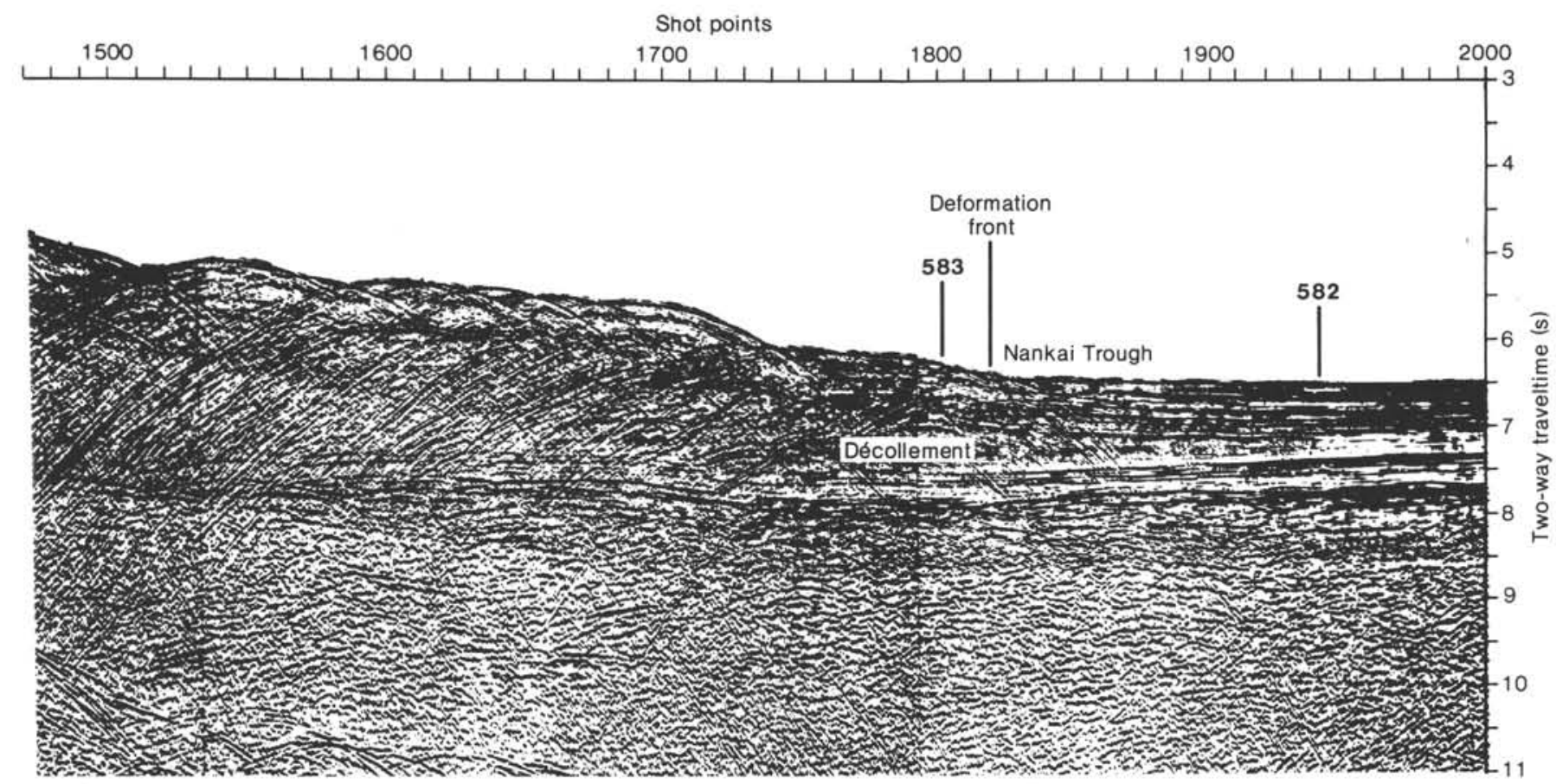

Figure 1. Migrated time section N55-3-1 (Nasu et al., 1982). (See Fig. 3 for location.)

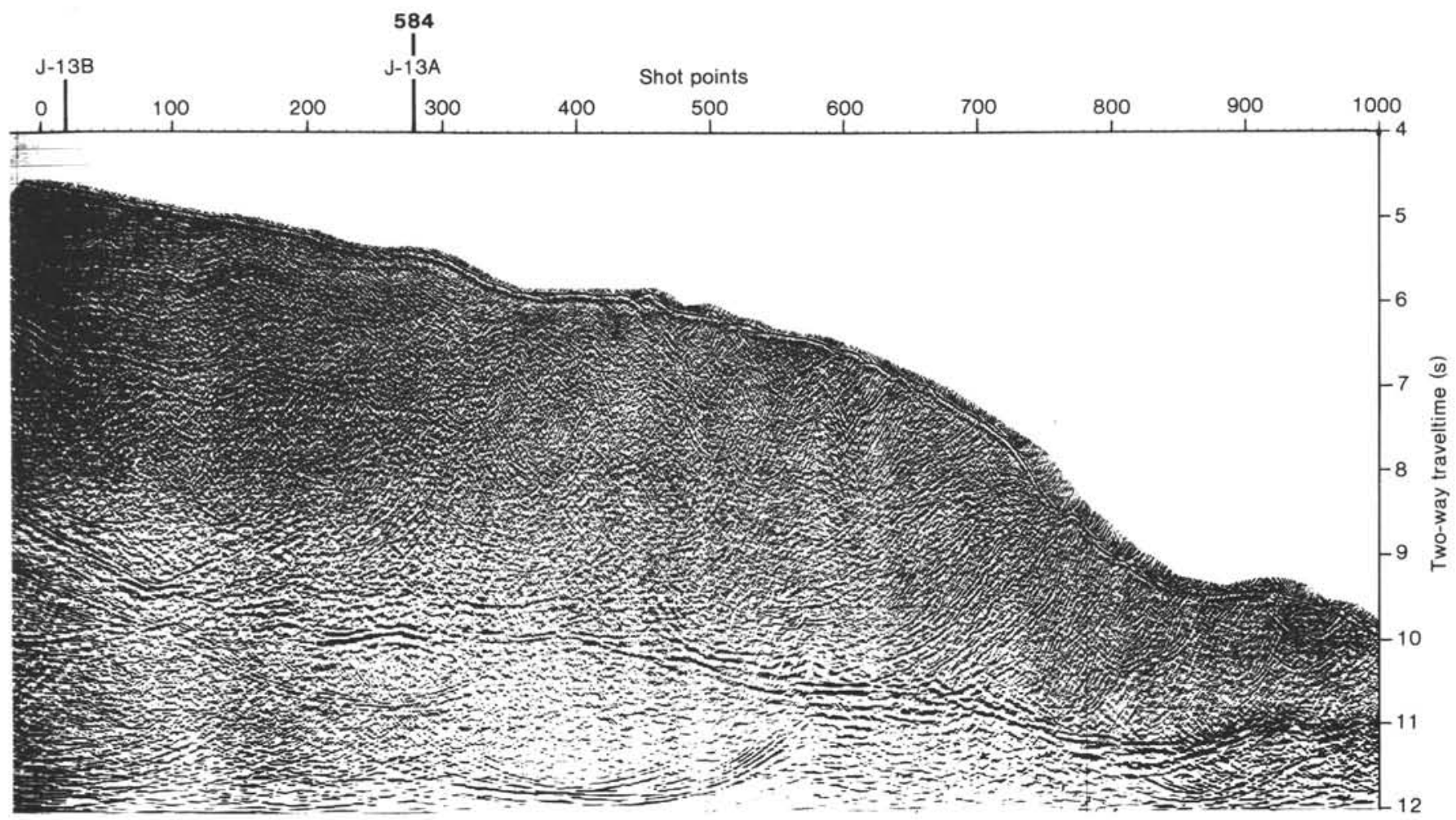

Figure 2. Migrated time-section ORI-78-3 (Nasu et al., 1979). (See Fig. 9 for location.)

sect along Profile N55-3-1 (Nasu et al., 1982; Aoki et al., 1982; and Claypool et al., this volume). Similar to features displayed in profiles across the Middle America Trench (Shipley et al., 1979), these reflectors are thought to represent the base of a layer of gas hydrate, an icy substance permeating the sediment. Absence of a BSR, however, does not indicate absence of gas hydrate, as results from DSDP Legs 67 and 84 drilling offshore of Guatemala have shown (Aubouin, von Huene, et al., 1982a; Aubouin, Stephan, et al., 1982). 


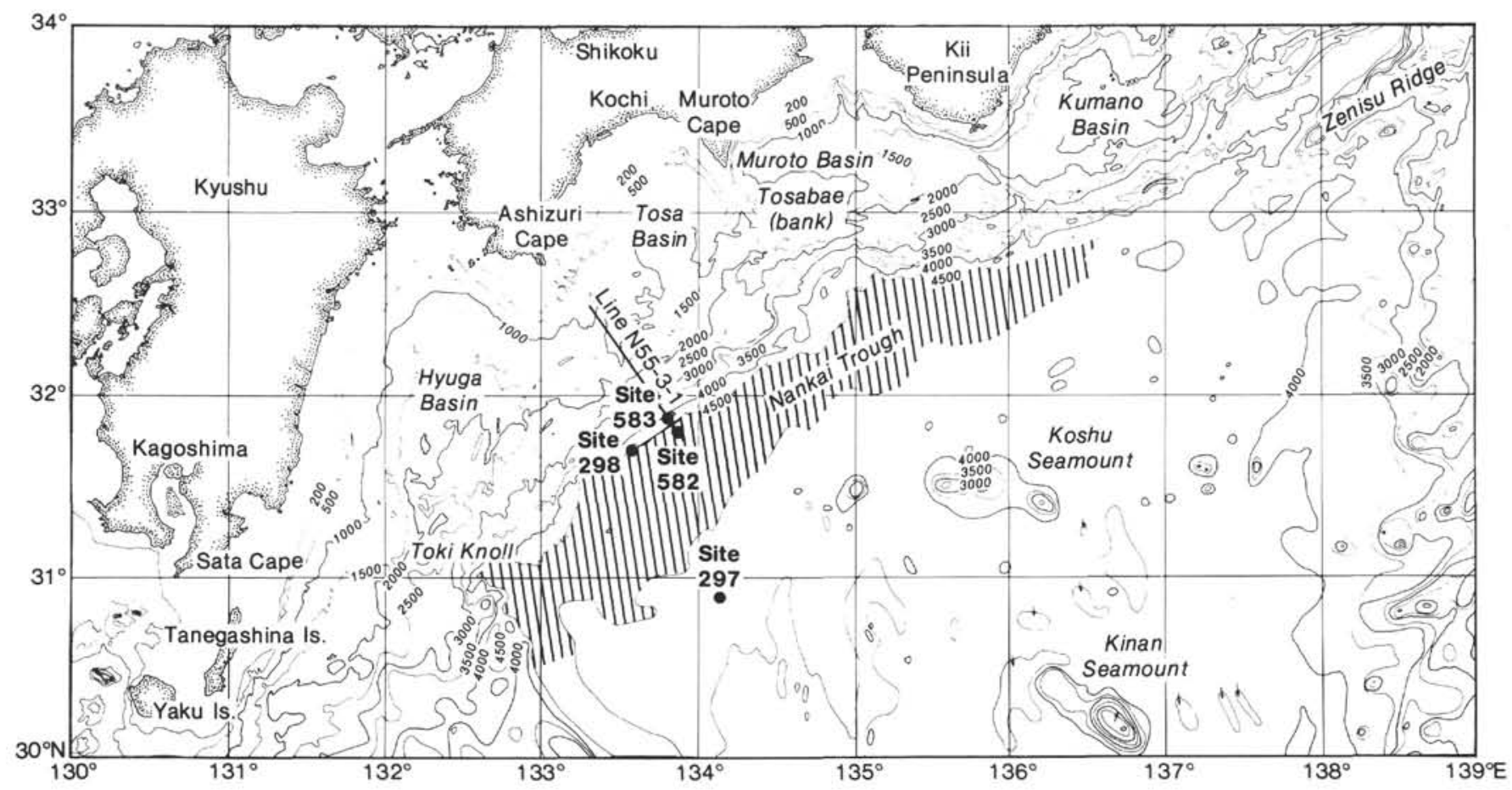

Figure 3. General bathymetry and prominent features of the Nankai Trough (after Nasu et al., 1982).

\section{Objectives and Events-Nankai Trough}

A transect of three sites was planned for the Nankai Trough. One site was to be located in the Trough axis and another two along the landward slope. The locations were selected to investigate: (1) subduction dynamics, namely the physical properties of sediments, (2) kinematics and structural evolution of the forearc, in particular, the identification of trajectories of sediment and rock in a subduction zone, and (3) sedimentation processes, primarily, a determination of the relative importance of gravitational and tectonic processes in the deformation of the trench slope and a refinement of concepts regarding sedimentation in deep-sea fans. Additionally, the magnetostratigraphy, biostratigraphy, tephrastratigraphy, and heat flow, paleoceanography, geochemistry of clathrates, and nature of pore water each were aspects of this investigation.

Because of a variety of mechanical problems and one typhoon, only two sites were drilled. The Glomar Challenger sailed from Tokyo on June 25, 1982 and arrived in the area offshore of Shikoku early on June 27, 1982 (Fig. 4). During this first part of Leg 87A, 10 holes were drilled at two sites, Site 582 in the axis of the Nankai Trough and Site 583 on the frontal thrust, or first step above the turbidites ponded in the Trough axis. Drilling at Site 582 penetrated the entire turbidite sequence of the Nankai Trough, and reached the Shikoku Basin sediment beneath. At its target depth within the landward slope, Site 583 failed to penetrate a reflector interpreted as the frontal thrust fault (Fig. 1), but did reach the reflector at a shallower sub-bottom depth. During attempts to $\log$ Site 583 the ship was required to return to Yokohama for repairs on the derrick. This change of plans

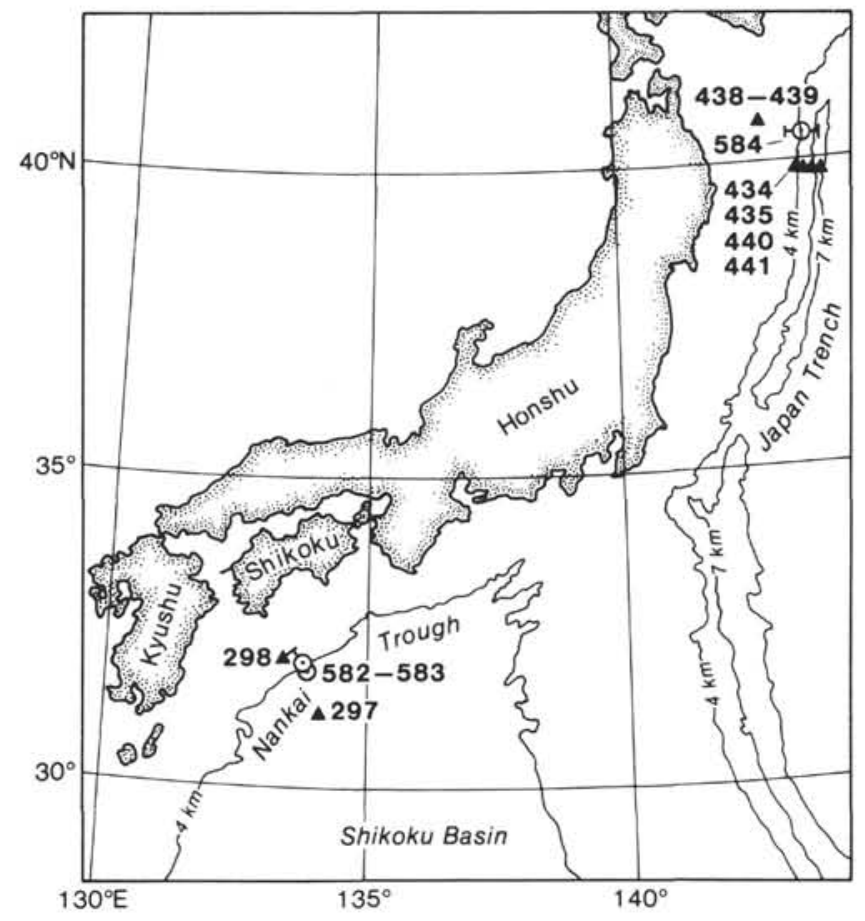

Figure 4. Location of drill sites offshore of Japan.

led to an early exchange of scientific personnel and also to the discovery of a mechanical failure in the corelatching mechanism, a failure that had already proved extremely costly to Leg 87A in terms of poor core recovery at Site 583. Upon leaving Yokohama Harbor, the Leg 87B scientific crew decided to return to the Nankai for yet another attempt to deepen Site 583. Drilling an 
eighth and final hole was begun at Site 583, only to end prematurely when the approach of Typhoon Bess forced the Challenger to its Leg 87B target, the Japan Trench (Fig. 4).

\section{Turbidites and Hemipelagic Mud of the Nankai Trough (Site 582-Unit 1)}

The three holes drilled at Site 582 are located in the Nankai Trough axis at $4882 \mathrm{~m}$ water depth. The first two holes attempted were abandoned because of mechanical difficulties. After about two days on site, drilling began in earnest at Hole 582B (Table 1, Fig. 5). The sedimentary sequence recovered is predictable, given the location of the site.

The uppermost $566 \mathrm{~m}$ cored (Cores 582-1 and 582-3; 582A-1 and 582A-2; and 582B-1 to 582B-54) are designated as Lithologic Unit 1 (Fig. 5), and represent the accumulation of turbidites and hemipelagic sediment deposited in the Nankai Trough (Site 582 chapter, this volume). Recovery averaged $41 \%$ for this interval, and much of the missing sample is probably sand, preferentially lost in the coring process. These unconsolidated, dark olive gray hemipelagic muds and sandy muds contain disseminated ash layers and scattered, isolated pumice grains. Illite and chlorite are the most abundant clay

Table 1. Coring summary: DSDP holes drilled during Legs 31, 56, 57 , and 87.

\begin{tabular}{|c|c|c|c|c|c|c|c|}
\hline Hole & $\begin{array}{l}\text { Latitude } \\
\text { (N) }\end{array}$ & $\begin{array}{l}\text { Longitude } \\
\text { (E) }\end{array}$ & $\begin{array}{c}\text { Water } \\
\text { depth } \\
\text { (m) }\end{array}$ & $\begin{array}{l}\text { Penetration } \\
\text { (m) }\end{array}$ & $\begin{array}{c}\text { Number of } \\
\text { samples }\end{array}$ & $\begin{array}{l}\text { Meters } \\
\text { cored }\end{array}$ & $\begin{array}{l}\text { Meters } \\
\text { recovered }\end{array}$ \\
\hline \multicolumn{8}{|c|}{ Nankai Trough } \\
\hline \multicolumn{8}{|l|}{ Leg 31} \\
\hline 297 & $30 \cos 2.36$ & 13409.89 & 4470 & 679.5 & 27 & 242.4 & 124.2 \\
\hline $297 \mathrm{~A}$ & 30952.36 & $134^{\circ} 09.89$ & 4470 & 200.5 & 0 & 0 & 0 \\
\hline 298 & $31^{\circ} 42.93$ & $133^{\circ} 36.22$ & 4649 & 611.0 & 16 & 145.5 & 66.8 \\
\hline $289 \mathrm{~A}$ & $31^{\circ} 42.93$ & $133^{\circ} 36.22$ & 4649 & 98.0 & 1 & 9.5 & 4.2 \\
\hline \multicolumn{8}{|l|}{ Leg 87} \\
\hline 582 & $31^{\circ} 46.51$ & $133^{\circ} 54.83$ & 4882 & 29.1 & 4 & 29.1 & 18.8 \\
\hline $582 \mathrm{~A}$ & $31^{\circ} 46.51$ & $133^{\circ} 54.83$ & 4882 & 48.5 & 2 & 19.4 & 16.3 \\
\hline $582 \mathrm{~B}$ & $31^{\circ} 46.51$ & $133^{\circ} 54.83$ & 4882 & 749.4 & 73 & 700.9 & 284.7 \\
\hline 583 & $31^{\circ} 50.00$ & $133^{\circ} 51.40$ & 4663 & 152.0 & 27 & 152.0 & 83.9 \\
\hline $583 \mathrm{~A}$ & $31^{\circ} 50.18$ & $133^{\circ} 51.26$ & 4622 & 54.0 & 11 & 54.0 & 47.8 \\
\hline $583 B$ & $31^{\circ} 49.76$ & $133^{\circ} 51.26$ & 4749 & 30.0 & 6 & 28.0 & 24.7 \\
\hline $583 \mathrm{C}$ & $31^{\circ} 49.80$ & $133^{\circ} 51.26$ & 4749 & 49.0 & 5 & 24.0 & 17.9 \\
\hline $583 \mathrm{D}$ & $31^{\circ} 49.76$ & $133^{\circ} 51.54$ & 4749 & 326.6 & 29 & 279.8 & 69.7 \\
\hline $583 E$ & $31^{\circ} 50.10$ & $133^{\circ 5} 1.30$ & 4655 & 198.7 & 5 & 48.3 & 1.0 \\
\hline $583 F$ & $31^{\circ} 50.10$ & $133^{\circ} 51.30$ & 4655 & 439.7 & 30 & 289.3 & 46.7 \\
\hline $583 G$ & $31^{\circ} 50.07$ & $133^{\circ} 51.40$ & 4653 & 450.0 & 15 & 143.4 & 62.1 \\
\hline \multicolumn{8}{|c|}{ Japan Treach } \\
\hline \multicolumn{8}{|l|}{ Leg 56} \\
\hline 434 & 39944.76 & $144^{\circ} 06.12$ & 5990.5 & 301.0 & 33 & 301.0 & $\$ 4.2$ \\
\hline $434 \mathrm{~A}$ & $39 \div 44.76$ & $144^{\circ} 06.12$ & 5988.0 & 160.5 & 2 & 18.0 & 14.6 \\
\hline $434 \mathrm{~B}$ & 3994.87 & $144^{\circ} 06.08$ & 5986.0 & 628.0 & 36 & 333.5 & 64.6 \\
\hline 435 & $39^{\circ} 44.09$ & $143^{\circ} 47.53$ & 3403.0 & 150.5 & 16 & 150.5 & 77.5 \\
\hline $435 \mathrm{~A}$ & $39^{9} 41.10$ & $143^{\circ} 47.59$ & 3404.0 & 244.5 & 11 & 95.0 & 46.1 \\
\hline \multicolumn{8}{|l|}{ Leg 57} \\
\hline 438 & 40937.75 & $143^{\circ} 13.90$ & 1547.5 & 109.5 & 12 & 109.5 & 81.9 \\
\hline $438 \mathrm{~A}$ & $40^{9} 37.79$ & $143^{\circ} 14.15$ & 1558.0 & 878.0 & 86 & 878.0 & 555.3 \\
\hline $438 \mathrm{~B}$ & $40^{\circ} 37.80$ & $143^{\circ} 14.80$ & 1564.7 & 1040.7 & 24 & 215.9 & 192.6 \\
\hline 439 & 3781.00 & $143^{\circ} 18.63$ & 1656.0 & 1157.5 & 39 & 342.0 & 163.1 \\
\hline 440 & $399^{\circ} 4.33$ & $143^{\circ} 55.74$ & 4507.0 & 73.0 & 8 & 73.0 & 50.4 \\
\hline $440 \mathrm{~A}$ & 3944.13 & $143^{\circ} 55.74$ & 4507.0 & 139.5 & 7 & 66.5 & 33.5 \\
\hline $440 B$ & $39^{\circ} 44.13$ & $143^{\circ} 55.74$ & 4507.0 & 814.0 & 71 & 814.0 & 401.9 \\
\hline 441 & $39 \% 45.05$ & $144^{\circ} 04.59$ & 5655.0 & 273.0 & 9 & 79.0 & 16.6 \\
\hline $441 \mathrm{~A}$ & $39^{\circ} 45.05$ & $143^{\circ} 04.59$ & 5646.0 & 662.0 & 15 & 138.5 & 19.7 \\
\hline $441 \mathrm{~B}$ & $39 \odot 45.08$ & $144^{\circ} 04.60$ & $\$ 640.0$ & 687.0 & 2 & 18.0 & 5.5 \\
\hline \multicolumn{8}{|l|}{ Leg 87} \\
\hline 584 & 40028.00 & $143^{\circ} 57.10$ & 4114.0 & 941.0 & 98 & 941.0 & 478.7 \\
\hline $584 \mathrm{~A}$ & $40^{\circ} 28.00$ & $143^{\circ} 57.60$ & 4115.0 & 901.5 & 3 & 28.9 & 10.7 \\
\hline $584 \mathrm{~B}$ & $40^{\circ} 28.00$ & $143^{\circ} 56.70$ & 4142.0 & 954.0 & 3 & 22.0 & 11.9 \\
\hline
\end{tabular}

minerals (Chamley and Cadet, this volume); and biogenic silica and quartz constitute 62 to $69 \%$ of the sediment (Minai et al., this volume). The sequence is graded, although alterations between four turbidite or sand layers and five intervening hemipelagic or muddy intervals are sometimes obscure, in part because of remolding by rotary-drilling deformation. Gas bubbled out of the core liners containing the first $200 \mathrm{~m}$ of sediment, further degrading the quality of the cores. The sediment was sufficiently indurated at about $250 \mathrm{~m}$ sub-bottom (Core 582B-22) to allow cutting cores with a saw. This method of core splitting preserved laminations, trace fossils, and the fissility of the sediment for viewing. Drill biscuits first appeared at about $295 \mathrm{~m}$ sub-bottom (Core $582 \mathrm{~B}-26$ ), and by $460 \mathrm{~m}$ sub-bottom the sediment was sufficiently indurated that Core 582B-44 contained only drill breccia.

Graded beds are particularly well displayed between 360 and $470 \mathrm{~m}$ sub-bottom (Cores 582B-33 to 582B-44, Site 582 chapter, this volume). In this interval, basal sand layers grade upward into silts and clays, the latter marked by Chondrites - trace fossils that appear as clusters of black dots in the dark olive gray matrix. An interval of mud, barren of these lebensspuren, usually separates the coarse basal layer of one cycle from the fine-grained upper member of the preceding event. The Chondrites-animal must have burrowed into the fine-grained upper members of the turbidite cycles, but later abandoned the location with the passage of time between events and the stagnation of bottom waters (Taira and Niitsuma, this volume). Benthic foraminifers are common in the coarsegrained basal layers, an indication of rapid transport and burial (Lagoe, this volume). The assemblages recovered are a mixture of species diagnostic of shelf to abyssal environments. Shallow-water and nonmarine diatoms are common at Site 582 (Akiba, this volume). Radiolarians are common immediately beneath the coarse-grained intervals, and sponge spicules are concentrated in white patches isolated in the muddy intervals. Faunal diversity is generally high for all microfossil groups due to a combination of mixing in the surface-water habitats of the Oyashio and Kuroshio and to mixing on the bottom by turbidity flows. The same layers also contain a suite of heavy minerals including hornblende, biotite, apatite, epidote, glaucophane, pyroxene, and zircon, components probably derived from the Tokai drainage basin to the northeast (Taira and Niitsuma, this volume). Fittingly, grain orientation analysis (Taira and Niitsuma, this volume) indicates transport along the axis of the Nankai Trough, presumably from the northeast.

\section{Hemipelagic Sediment of the Shikoku Basin (Site 582-Unit 2)}

The lithologic contact between sediments deposited in the Nankai Trough and those rafted into the subduction zone on the Philippine Plate is gradational over an interval of about $20 \mathrm{~m}$. Somewhat arbitrarily, that contact, the top of Lithologic Unit 2, is designated as $566 \mathrm{~m}$ sub-bottom (Core 582B-54/55). The interval between 537 and $566 \mathrm{~m}$ sub-bottom at Site 582 is one of poor core recovery. A seismic reflector, placed between 540 and 

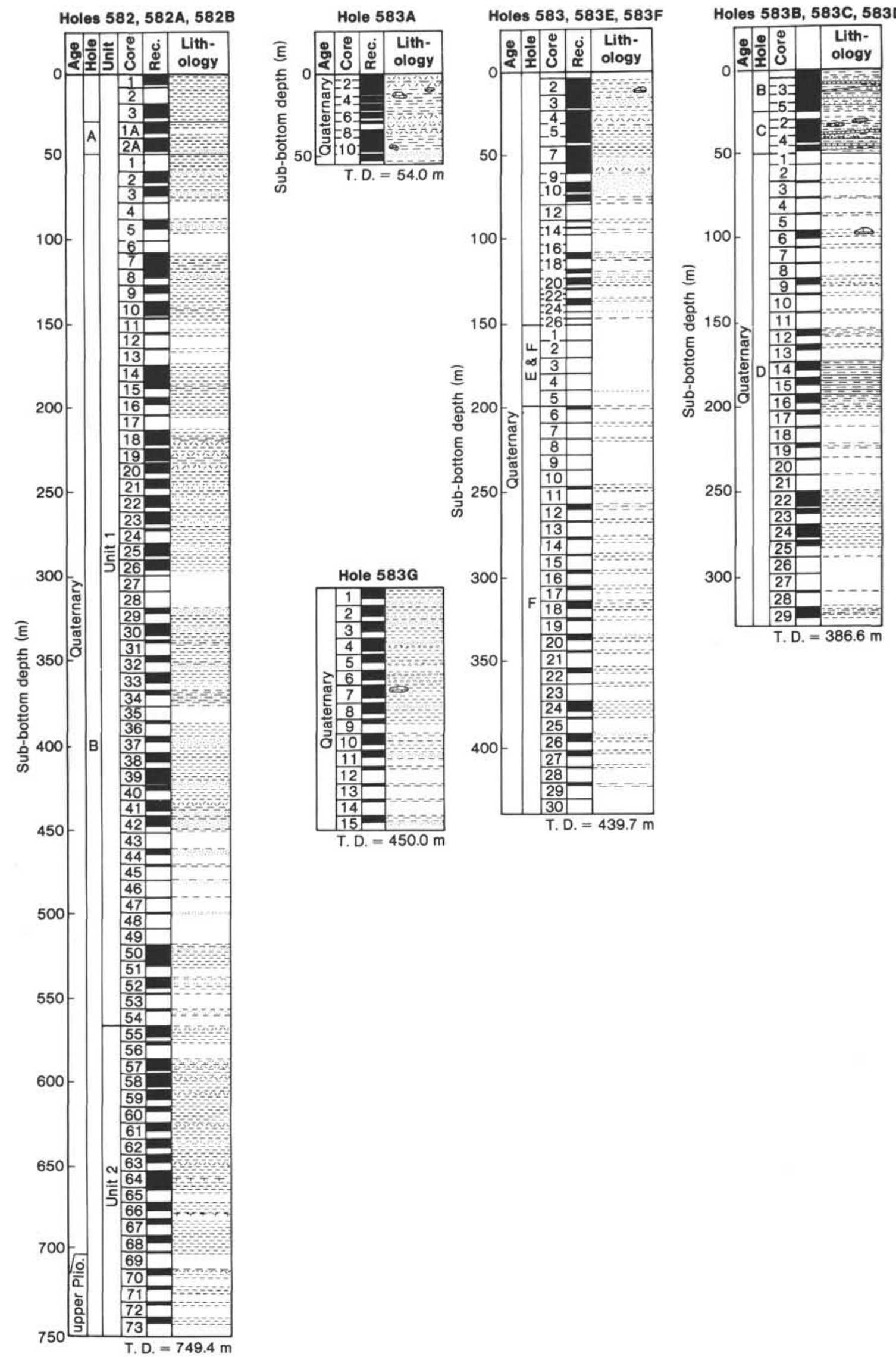

Figure 5. Summary lithologic columns for Leg 87A Nankai Trough drill holes. 
$580 \mathrm{~m}$, may mark this facies change, but reflectors abound in this section: 13 are listed and 5 are considered "marker horizons" (Seismic Stratigraphy section, Site 582 chapter, this volume). Sediment porosity is another indicator of the lithologic transition. Porosity decreases systematically from the seafloor to $525 \mathrm{~m}$ sub-bottom, then increases over the next $100 \mathrm{~m}$, only to resume a general decrease from $625 \mathrm{~m}$ to the base of the hole at $749.4 \mathrm{~m}$ sub-bottom.

Several aspects of the sedimentary lithology discriminate the two facies. The Shikoku Basin hemipelagic sedimentary sequence is slightly greener and more varicolored, and it lacks the graded-bed Chondrites-rich sequences so prominent in the overlying section. Instead, Zoophycos and Planolites traces are abundant. These lebensspuren are absent in Unit 1. Although rare, the benthic foraminifers recovered are all deep-water species. Buff-brown nannofossil-rich blebs and drilling-deformed layers and large ( $2 \mathrm{~cm}$ in diameter), isolated pumice clasts stand out in sharp contrast amidst the dark matrix of these cores. Radiolarians are absent in Unit 2. Healed normal faults cut across Cores 582B-62 to 582B-64 (Site 582 chapter, this volume), and anastomosing veinlets occur in Core 582B-62 (633-637.8 m sub-bottom). As expected, these veinlets are rare and poorly developed in the axial sediment cored at Site 582 but are common features of forearc sediments, occurring in the Japan and Guatemalan forearcs (Arthur et al., 1980; Cowan, 1982).

\section{Accumulation Rates (Site 582)}

Accumulation rates for the section drilled at Site 582 range from $900 \mathrm{~m} / \mathrm{Ma}$ before $0.4 \mathrm{Ma}$ to $300 \mathrm{~m} / \mathrm{Ma}$ after $0.4 \mathrm{Ma}$ (Site 582 chapter, this volume). These results are broadly averaged and depend on a nannofossil and a radiolarian datum between 68 and $108 \mathrm{~m}$ sub-bottom (Cores 582B-4 and 582B-7; Lang, this volume; on a magnetic reversal-the Bruhnes/Matuyama Epoch boundary at $607 \mathrm{~m}$ sub-bottom (Niitsuma, this volume); and on another nannofossil datum-the Pleistocene/Pliocene boundary at $712 \mathrm{~m}$ sub-bottom (Section 582B-70-2). Although the biostratigraphic resolution is poor (even diatoms are rare), all indications point to a reduced rate of accumulation in the uppermost portion of the sedimentary column. The result is surprising, given the present location of Site 582 in the axis of the Nankai Trough, but a variety of explanations are plausible. Variable conditions, such as shifting depocenters along the axis of the Nankai Trough or multiple sediment sources, are just some of the possibilities (see Sediment Accumulation Rates section-Site 582 chapter, this volume).

Despite the high accumulation rates, organic carbon content is low, less than $0.77 \%$ throughout (Mukhopadhyay et al., this volume), and generally decreases below $500 \mathrm{~m}$ sub-bottom (Site 582 chapter, this volume). Site 582 sediment is anoxic at only $1 \mathrm{~m}$ depth, despite the limited biological activity indicated by the low organic carbon content (Claypool et al., this volume). Rapid accumulation of sediment has probably induced the anoxic conditions observed by inhibiting oxygen diffusion in the lithologic column.

\section{Regional Stratigraphy}

A comparison of the two lithologic units recovered at Site 582 with those of Sites 297 and 298, drilled during Leg 31 (Karig, Ingle, et al., 1975), is not rewarding. Site 297 is located seaward of the Nankai Trough (Fig. 3), and, as expected, the Shikoku Basin sediments cored from beneath $566 \mathrm{~m}$ sub-bottom (Hole 582B, Unit 2) represent a facies similar to that of the uppermost lithologic unit at Site 297. Hole 298 was drilled into the landward slope of the Nankai Trough (Fig. 3). The distal turbidites cored there between 180 and $611 \mathrm{~m}$ sub-bottom are probably the counterparts of those cored in the uppermost $566 \mathrm{~m}$ at Site 582 (Unit 1), but a lack of diagnostic elements and spot coring at Site 298 (of the $611 \mathrm{~m}$ penetrated, only $71 \mathrm{~m}$ were actually recovered-Table 1) allows only a tenuous correlation (Ingle et al., 1975; and Sedimentology section, Site 582 chapter, this volume).

Turbidites, Hemipelagic Mud and Mudstone, and Authigenic Carbonates of the Landward Slope (Site 583)

Originally, two holes were planned for Site 583. A "safety" hole of shallow penetration was to test for the presence of gas by penetrating the frontal thrust (landward-dipping reflector) at about $300 \mathrm{~m}$ sub-bottom. At that depth hydrocarbons are expected to occur as solid hydrate rather than as gas. Providing that the gas content was low at the first hole, a second hole would be drilled slightly landward and to a greater sub-bottom depth. That second hole was to penetrate this same frontal thrust at $600 \mathrm{~m}$ sub-bottom where the sedimentary section would be more lithified and chances of recovery better than at $300 \mathrm{~m}$ sub-bottom. Attainment of these objectives was plagued by a variety of difficulties including: positioning problems, communications delays, loss of a core barrel and heat probe in one hole, a prematurely released drill bit, a failed core-latching mechanism, cracks in the guide rail support padeye of the derrick itself, and, ultimately, the approach of a typhoon. Eight holes were drilled at this site and involved two different scientific crews (see Operations section, Site 583 chapter, this volume). The first four holes were hydraulically piston cored and the last four were rotary cored.

The four hydraulic piston core (HPC) holes were very successful, both on an individual basis, for the wealth of detail preserved, and collectively, because the holes made it possible to assess the degree of variability in stratigraphy that can be expected in this setting. Highresolution images of the seafloor were lacking, so the location of these holes with respect to the surrounding morphology is based on $3.5-\mathrm{kHz}$ profiles (Site 583 chapter, this volume). Hole 583A is the farthest landward of any of the holes drilled on the terrace at Site 583. Hole 583 sampled the sedimentary cover at a location designated for the Site 583 deep hole located farther seaward, Holes 583B and 583C sampled the location of the planned Site 583 safety hole (Fig. 5). The entire $152 \mathrm{~m}$ of sediment HPC cored is Quaternary in age.

The cut cores from each of these holes display sequences of finely graded beds, most cycles less than 10 
$\mathrm{cm}$ thick. The $54 \mathrm{~m}$ of sediment recovered from Hole $583 \mathrm{~A}$ is representative of that sampled at each of the HPC holes: dark olive gray hemipelagic mud with gray silt layers that are usually graded and have sharp erosional bases (Fig. 6A). Plant fragments are common in these slope sediments, and pyrite is more abundant at Hole 583A than at the other HPC holes. A prominent light gray layer of ash occurs in Core 583A-6 (27 m subbottom). These cores also contain pale brown carbonate crystalline aggregates. Identified as ikaite (Stein and Smith, this volume), these porous crystalline masses are similar to calcium carbonate hexahydrates recovered from organic-matter-rich sediments of the Antarctic Shelf (Suess et al., 1982). As large as $5 \mathrm{~cm}$, these aggregates were so fragile that they would have been completely dispersed and probably lost to the observer had the hole been rotary cored. They were confined to the basal, pyritic, silty and sand layers of turbidite cycles rich in plant debris (Fig. 6B and 6C). Unstable at surface pressure and temperature, these crystals had completely disappeared by the time of the Leg 87 postcruise meeting, one year later. Only the rhombohedral molds of the aggregates are left as an indicator of their former presence. The gas content at Hole 583A is also exotic compared with that sampled at the other seven holes on this slope; concentrations of butane and pentane are relatively high but the methane/ethane ratio is also high. Fortunately for drilling prospects on this margin, these high gas concentrations occurred only at the location of Hole 583A.

HPC coring at Holes 583C and 583D produced some unexpected results; namely, a sequence of strongly dipping graded beds-the lithologic equivalents of those cored at Holes 583 and 583A. Because these beds dip seaward, then flatten abruptly at the base of the hole, they are interpreted as the seaward limb of a hangingwall anticline (Fig. 6D), Lundberg and Karig, this volume; Niitsuma, this volume).

The safety hole, 583D, was rotary cored at the location of Holes 583B and 583C. Drilling was slow and recovery poor $(25 \%)$. Because of the coring method, the meager sedimentary record recovered is severely remolded and more closely resembles the rotary-cored sediment from the Nankai Trough axis than the HPC sediment cored from immediately above. Dark gray hemipelagic mud constitutes the bulk of the recovered sedimentary section. Although not rewarding in a sedimentological sense, drilling at Hole 583D demonstrated that the gases do not pose a safety threat to those drilling on this slope (Site 583 chapter, Mukhopadhyay et al., and Claypool et al., all this volume). Holes 583E, 583F, and 583G were positioned near the location of HPC Hole 583. Recovery was so poor at $583 \mathrm{E}$ that the hole was abandoned to allow inspection of the bottom hole assembly (BHA) for a failed core-latching mechanism. When no obvious problem was found, Hole $583 \mathrm{~F}$ was drilled with almost the same lack of recovery. Only after the ship returned to Tokyo for repair of the derrick was a fault in the latching mechanism found.

The sediment recovered from the Site 583 rotary-cored holes resembles Lithologic Unit 1 of Site 582 . This dark olive gray hemipelagic mud and sandy mud becomes firm near $180 \mathrm{~m}$ sub-bottom (Core 583D-15), where the first drill biscuits are encountered, and is sufficiently indurated at $355 \mathrm{~m}$ sub-bottom (Core 583G-6) to merit the descriptor "mudstone." Again, sands are probably selectively lost in the coring process. Quartz, plagioclase, albite, smectite, chlorite or kaolinite, illite, calcite, dolomite, and siderite are identified by their X-ray diffraction peaks (Site 583 chapter, this volume). A decrease of amphibole and smectite downhole suggests a change of sediment source. Large pumice clasts, ash-rich blebs, and deformed ash layers are scattered throughout. Several large carbonate nodules were recovered, the largest in Section 583G-17-2 and others at 343, 367, and $489 \mathrm{~m}$ sub-bottom in Hole 583G. Both siliceous and calcareous microfossils are poorly preserved and only common to rare; the oldest sediment cored at Site $\mathbf{5 8 3}$ is late Quaternary.

Sands are irregularly distributed throughout the section. Sand was recovered in Cores 583D-16 and 583D-19, Cores 583G-2, 583G-4, 583G-8, 583G-11, and 583G-16; muddy sands in Cores 583D-4 and 583D-5; and graded silts in Cores 583D-9, 583D-11, and 583D-13. Primary sedimentary structures in these coarse-grained sediments are remolded by drilling. The thicker the graded layers, the coarser are their basal layers. Sandy intervals are arkosic, containing as much as $\mathbf{3 5 \%}$ feldspar. These sands carry biotite, amphibole, pyroxene, zircon, epidote, rutile, and glaucophane as accessory minerals. Plant debris is common in the coarse-grained intervals, especially in Section 583G-1-3, where the interval near $60 \mathrm{~cm}$ is packed with wood flakes. Like the upper part of the stratigraphic section at Site 582, the deeper cores (583D-23 and beneath) contain graded silts, scattered dark gray green laminations, and trace fossils of Chondrites. Core 583D-29 is a particularly good example of this combination of features (see Sedimentology section, Site 583 chapter, this volume). Sands are probably underrepresented in the recovered sediment, because well-logs indicated their presence over a much broader sub-bottom range (see Logging section, Site 583 chapter, this volume).

Where reconstructed paleomagnetically, most bedding dips measured indicate a southeasterly tilt of the strata cored at Holes 583D and 583G, probably the result of intraformational deformation where thick sand beds are involved (Niitsuma, this volume). Faint dark zones occur in uniform sets, crossing the core at about a $60^{\circ}$ angle (Cores 583F-24 to 583F-26 and within and below Core 583G-10). They are referred to as incipient kink bands (see Structural Geology section, Site 583 chapter, this volume).

The abrupt changes in physical properties of the sediment expected at 60 and $160 \mathrm{~m}$ sub-bottom, where coring intersected major reflectors interpreted as thrust faults (Fig. 1), did not materialize (Bray and Karig, this volume). The sediment is fissile and porosity decreases as shear strength increases with sub-bottom depth. The porosity gradient at Site 583 is less than that of the trenchfill sediments at Site 582; and the average porosity in the entire section at Site 583 (down to basement) is much less than that at Site 582 (Bray and Karig, 1985). Frac- 
tures occur in the mudstone below $353 \mathrm{~m}$ sub-bottom (Core 583F-22). Although they are diagnosed as tectonic in origin (Lundberg and Karig, this volume) because none is healed, the possibility of their formation during the drilling process cannot be ruled out.

\section{Regional Stratigraphy}

The limited amount of sediment recovered at Site 583 is equivalent to that recovered in Unit 1 of Site 582 (Sedimentology section, Site 583 chapter, this volume). A facies change may exist, because the pyrite-rich, graded silty layers recovered in the HPC cores are not present in the rotary-cored samples from Site 582. Without HPC cores from the Nankai Trough axis, the relationship of the finely bedded slope turbidites to regional sedimentary processes remains unknown. The sequence cored at Site 583 HPC holes may represent distal turbidites from the slope or overbank deposits of turbidity flows moving down the Trough axis.

Site 298 is located only about $20 \mathrm{~km}$ to the southeast of Site 583, but an equivalent of Unit 1 of Site 298 (a cobble-bearing clayey and silty sand and clay) was not recovered at any of the Site 583 holes. Unit 2 of Site 298 $(194.2$ to $611 \mathrm{~m})$ is described as a fissile clay(stone), silt(stone), and clayey and silty sand (Ingle, Karig, et al., 1975), similar to the facies recovered at Site 583.

\section{JAPAN TRENCH-LEG 87B}

\section{Geologic Setting}

The Japan Trench strikes north-south for almost $900 \mathrm{~km}$ offshore of northern Honshu Island and has most of the attributes considered typical of convergent margins. The Sea of Japan is a back-arc basin; Honshu is part of a magmatic arc; a thickly sedimented forearc basin separates the volcanic arc from the Trench; the Trench is a pronounced submarine feature exceeding $7000 \mathrm{~m}$ depth; and a seismically active Wadati-Benioff zone outlines the descent of the Pacific Plate along this subduction zone.

DSDP drilling efforts have concentrated on the forearc in the Sanriku area, a deep-sea terrace off the Pacific side of Honshu. Leg 87B drilled about $42 \mathrm{~km}$ landward of the Trench axis between two transects of Leg 56,57 sites $(584$, Fig. 7$)$. This slope is depicted as thickly sedimented in geologic cross sections (see fig. 1 of von Huene et al., 1982, after Ishiwada and Ogawa, 1976) with irregularly distributed local depocenters (Uyeda, 1974). From Site 584 the upper slope rises gradually to Sites $483-439$, and the lower slope drops steeply to the Trench axis at $7300 \mathrm{~m}$ depth (Fig. 2). Viewed in detail in the various processed displays of Profile ORI 78-3 (Nasu et al., 1979), the pronounced subhorizontal reflectors between Shot Points (SP) 0 and 130 extend seaward, but become less distinct toward Site 584 (Fig. 2). A pronounced reflector that rises to almost $1 \mathrm{~s}$ sub-bottom depth at SP 280 was the deep objective at Site 584. Although the site is placed on a depth transect of sites (Fig. 8), some caution is advised in interpreting this projection. Such an illustration assumes uniformity of fa- cies along strike, a generalization that has many exceptions.

\section{Drilling Objectives and Events, Japan Trench}

Interpretation of the drilling results from six Leg 56, 57 sites in the Sanriku area (Fig. 8, Table 1), has allowed construction of a history of regional subsidence since the Miocene. A slight amount of uplift may have followed in the Pleistocene (fig. 33 of Arthur et al., 1980; and fig. 10 of von Huene et al., 1982). Regional subsidence was inferred almost 20 years before DSDP drilling. Iijima and Kagami (1961) reported the recovery of wind-eroded and wave-eroded Miocene sedimentary rocks in dredge hauls from the outer edge of the deep-sea terrace, and Sato (1973) proposed a foundered landmass as a source for those deposits. Sugimura (1972) speculated that a portion of the island arc was removed in the course of Cenozoic subduction of the Pacific Plate. All of these inferences were borne out during Leg 56, 57 drilling, which reached the upper surface of the foundered Oyashio landmass. Located on seismic lines shot between the Leg 56, 57 profiles (Fig. 7), sites J-13A, $\mathrm{J}-13 \mathrm{~B}$, and $\mathrm{J}-16 \mathrm{~B}$ were to elaborate on this history of vertical motions and to investigate (1) the physical properties of slope sediments, (2) the history of explosive volcanism, and (3) the history of deformation of slope sediments. Of the suite of sites proposed, locations J-13A and $\mathrm{J}-13 \mathrm{~B}$ on the midslope terrace were rated as the highest priority, and J-16B as an alternate. Because of the extra days devoted to the return of Leg $87 \mathrm{~B}$ to Hole 583G in the Nankai Trough, the time remaining to drill in the Japan forearc was reduced. This shortage of time was the primary concern and led to more widely spaced spot coring of Holes 584A and 584B than the scientific crew would have liked.

\section{Diatomaceous Hemipelagic Mudstone of the Japan Forearc (Hole 584)}

Four lithologic units and seven subunits describe the $954 \mathrm{~m}$ drilled at Site 584 (Fig. 9). These designations are based on minor changes and were established for the sake of convenience. The section is homogeneous from top to bottom, and all lithologic changes are subtle and gradational (see Sedimentology section, Site 584 chapter, this volume). Diatom content decreases uniformly from more than $60 \%$ in the near-surface cores to less than $10 \%$ at $650 \mathrm{~m}$ sub-bottom (Core 584-68) and beneath (Fig. 9). All other microfossil groups are absent or only poorly represented. X-ray fluorescence places the estimated silica content between 67 and $88 \%$ with an irregular, but overall decrease downcore (Minai et al., this volume). The first $4 \mathrm{~m}$ at Hole 584 (Sections 584 -1 and 584-1-2) are upper Pleistocene sediment underlah without a lithologic contrast at Core $584-1-3,30 \mathrm{~cm}$ by soft, lower Pleistocene diatomaceous mud and mudstone. This layer of Quaternary sediment contains abundant diatom resting-spores, which reappear in the upper Miocene between 550 and $620 \mathrm{~m}$ sub-bottom (Akiba, this volume) in association with two pronounced manganese enrichments and concentrations of carbonate nodules 

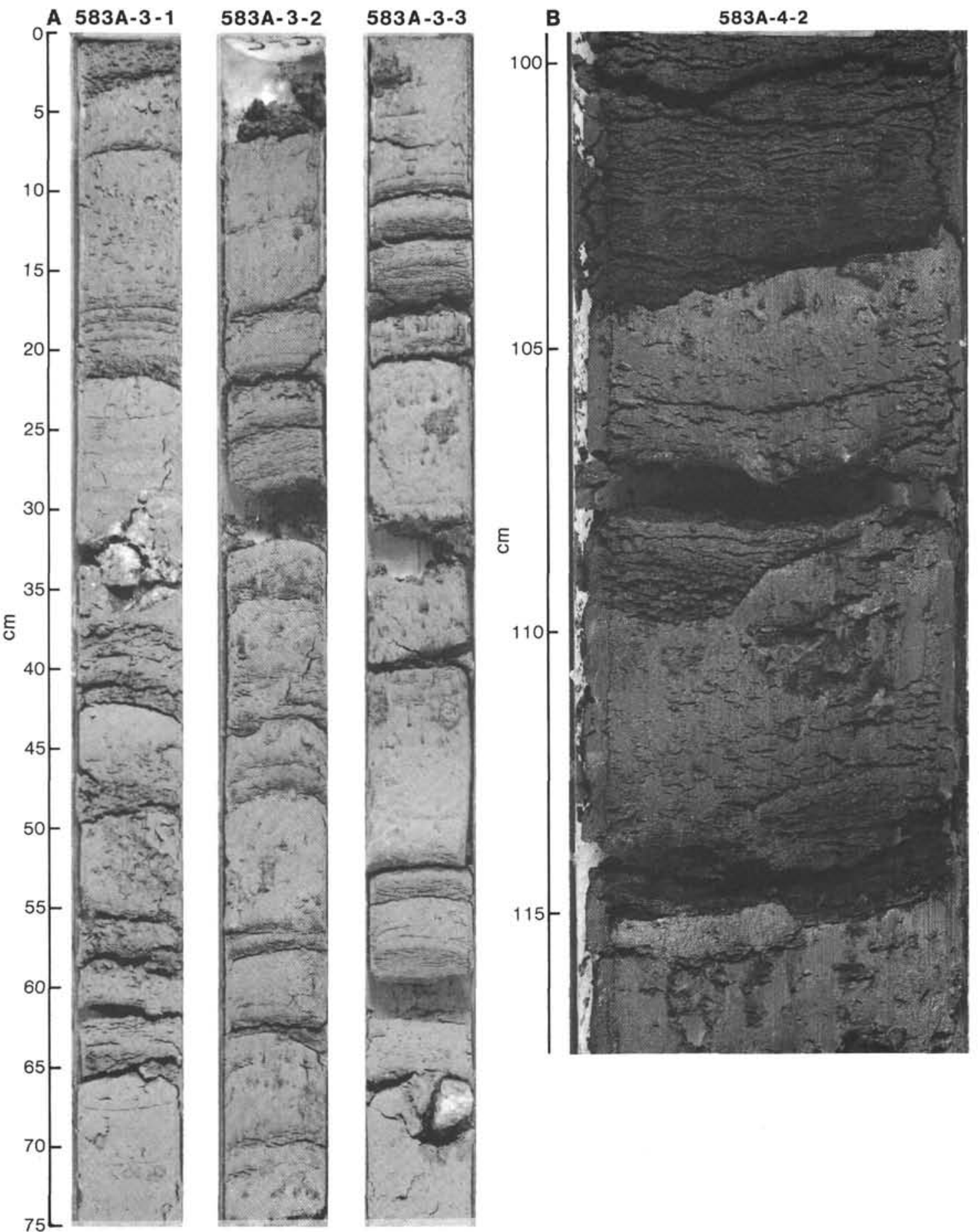

Figure 6. HPC sediment from the landward slope of the Nankai Trough. A. Core 583A-3, turbidite cycles and carbonate aggregates. B. Section 583A-4-2, detail of turbidite sequence. C. Section 583A-3-4, calcium carbonate hexahydrate nodule. D. Sections 583C-2-1, 583C-2-2, 583C-2-4, calcium carbonate hexahydrates. E. Sections 583B-2-1, and 583B-2-2, dipping turbidite layers.

(Fig. 10; Matsumoto et al., this volume). The paleoenvironmental significance of these concentrations is uncertain at this time.

The sediment becomes sufficiently consolidated near $88 \mathrm{~m}$ sub-bottom (Section 584-10-3) to generate drilling- induced laminae. Drilling biscuits are common beginning at $183 \mathrm{~m}$ sub-bottom (Section 584-20-1), and by $250 \mathrm{~m}$ sub-bottom (Core 584-27), the sediment is hard enough to be designated as a "mudstone." The Pliocene/Miocene boundary occurs near $432 \mathrm{~m}$ sub-bottom 

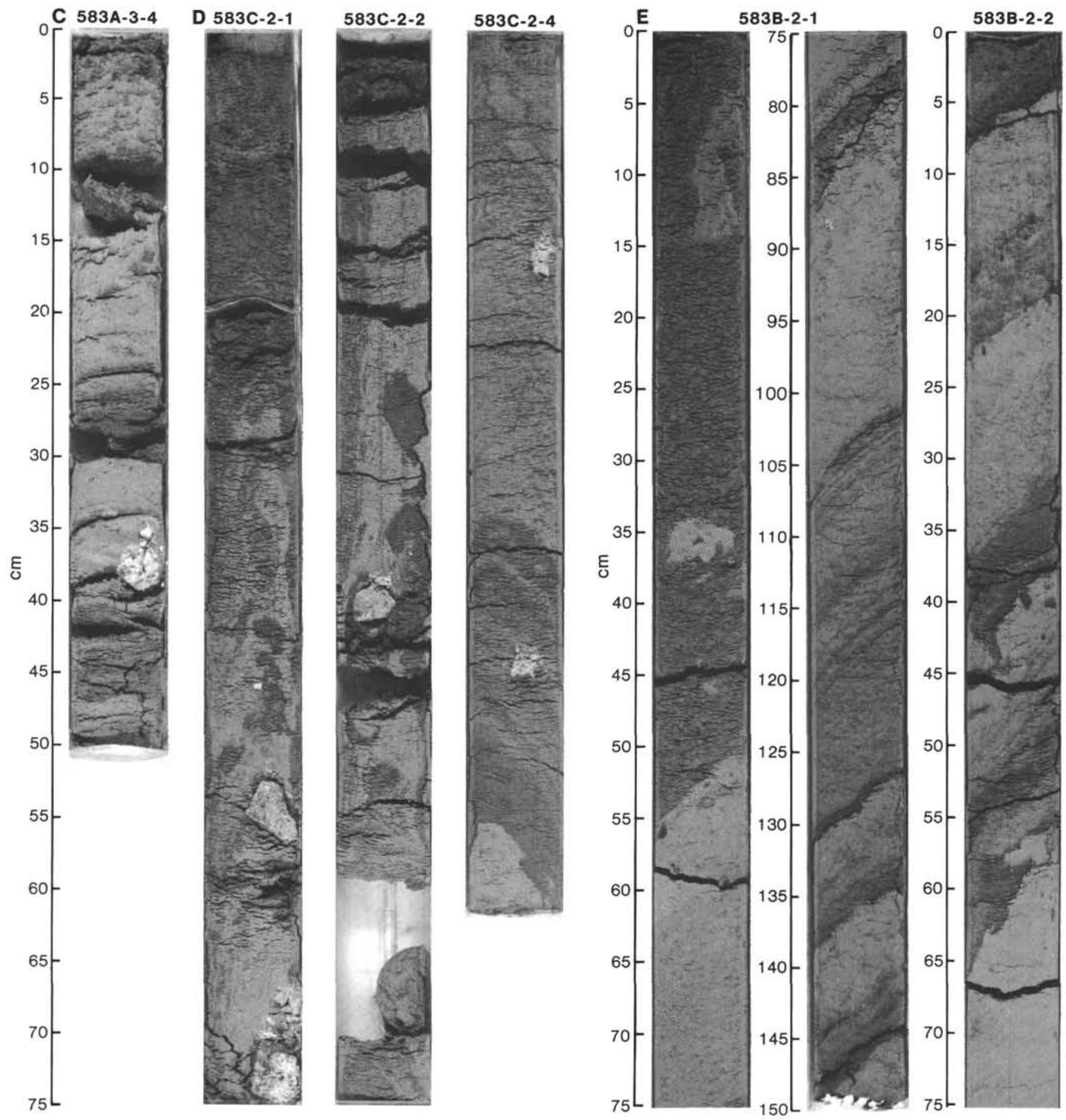

Figure 6. (Continued).

in Core 584-46 (Akiba, this volume: a revision of shipboard estimates that placed the boundary at $354 \mathrm{~m}$ subbottom, Cores 584-37/38 contact). As at the Pleistocene/ Pliocene boundary, no lithologic contrast marks this event; however, large ion lithophile (LIL) elements are enriched below this level (Minai et al., this volume). This enrichment corresponds to levels recorded for the Nankai Trough and slope sediments. The contrast at the Site 584 Pliocene/Miocene boundary suggests a change in ocean currents at the end of the Miocene-the Kuroshio now carries Nankai-like sediments seaward and well to the east of the Sanriku area (Minai et al., this volume).

As the diatom content gradually decreases, bioturbation (Fig. 11) and the occurrence of healed fractures ac- 


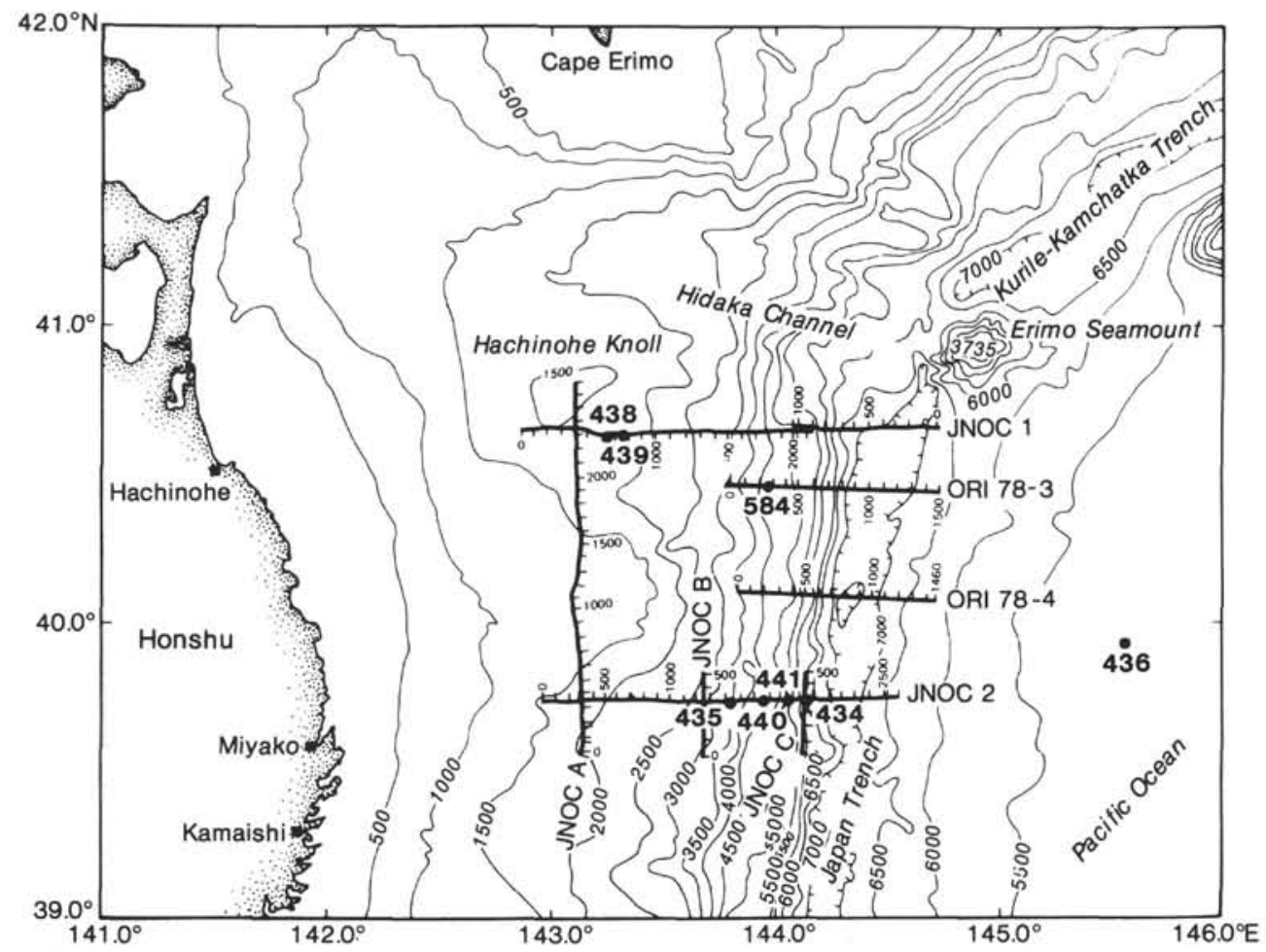

Figure 7. General bathymetry and prominent features of the Sanriku area of the Japan Trench offshore of northeastern Honshu Island.
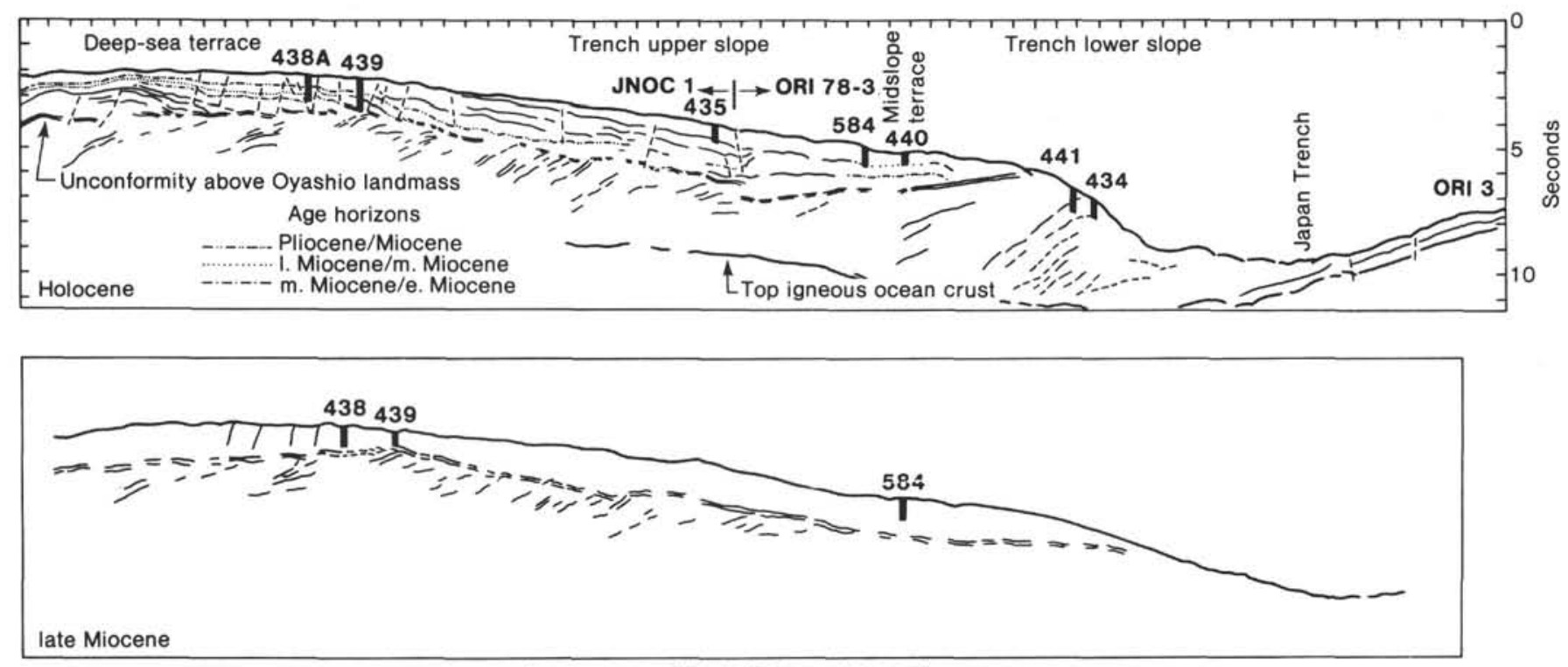

(composite profile JNOC $1+$ ORI 78-3)

Figure 8. Projection of DSDP Japan Trench sites onto a transect crossing the forearc.

companied by elaborate networks of dewatering veinlets gradually increase downhole (Fig. 12). These veinlets branch and terminate at overlying coarse layers and presumably represent avenues of pore water escape (Cowan, 1982; Ogawa and Miyata, 1985; Ritger, 1985).

In most cases, the healed fractures preserve a record of small-scale normal faulting, but examples of reverse faulting are also common. The most striking example of local extension is in the pull-apart feature recovered in Section 584-71-2 (Fig. 13). As this gap opened, pieces peeled off of the side walls and were enveloped in the darker, infilling matrix. The sedimentary and structural features combine to produce a "paisley" or varicolored appearance in the lower part of the Site 584 lithologic section. The whole had a turquoise green coloration immediately after core splitting, which gave the surface a 

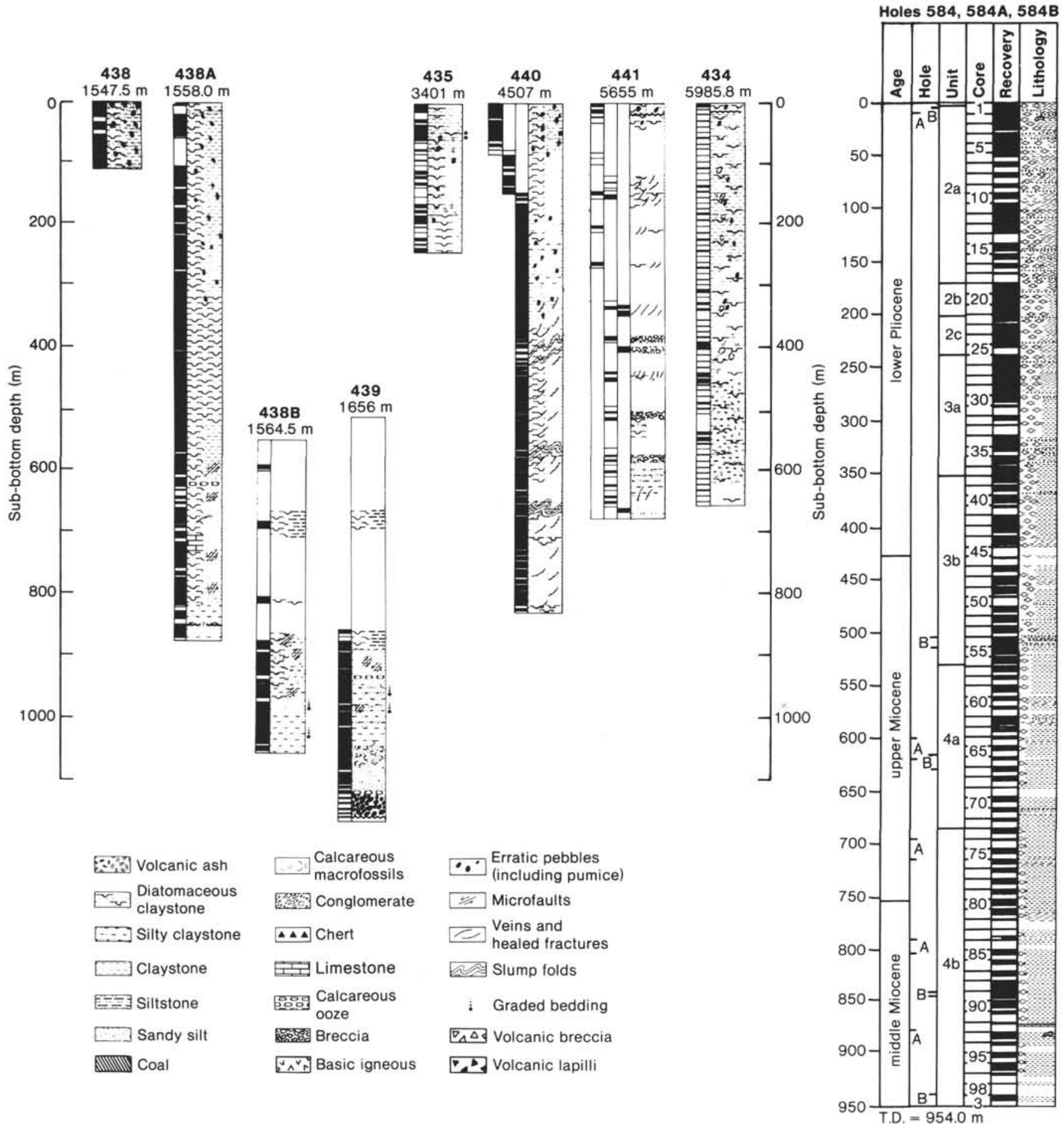

Figure 9. Summary lithologic columns for Leg 56, 57 and Leg 87B drill holes on the Japan Trench forearc.

decorative aspect that would be appropriate for ornamental building stone. Unfortunately, the coloration was lost within $24 \mathrm{hr}$. after refrigeration. Steeply dipping beds add an element of abstraction to core slabs. Bedding dips are prominent as high as Core 584-48 in the section; these increase to $35^{\circ}$ by Core $584-57$ and reach a maximum of $64^{\circ}$ apparent dip in Core 584-85 (Site 584 chapter, this volume). These sedimentary rocks are assigned to the lowest diatom zone of the middle Miocene (Aki- ba, this volume), and as such are the oldest rocks yet recovered from the seaward edge of the Japan forearc.

The frequency of ash layers, dispersed glass, and ash pods suggests that onshore volcanic activity increased toward the end of the late Miocene and continued through the early Pliocene (see Sedimentology section, Site 584 chapter, this volume, and Fujioka, this volume). This pattern follows the record of subaerial explosive volcanism (Konda, 1974; Isshiki, 1977). 


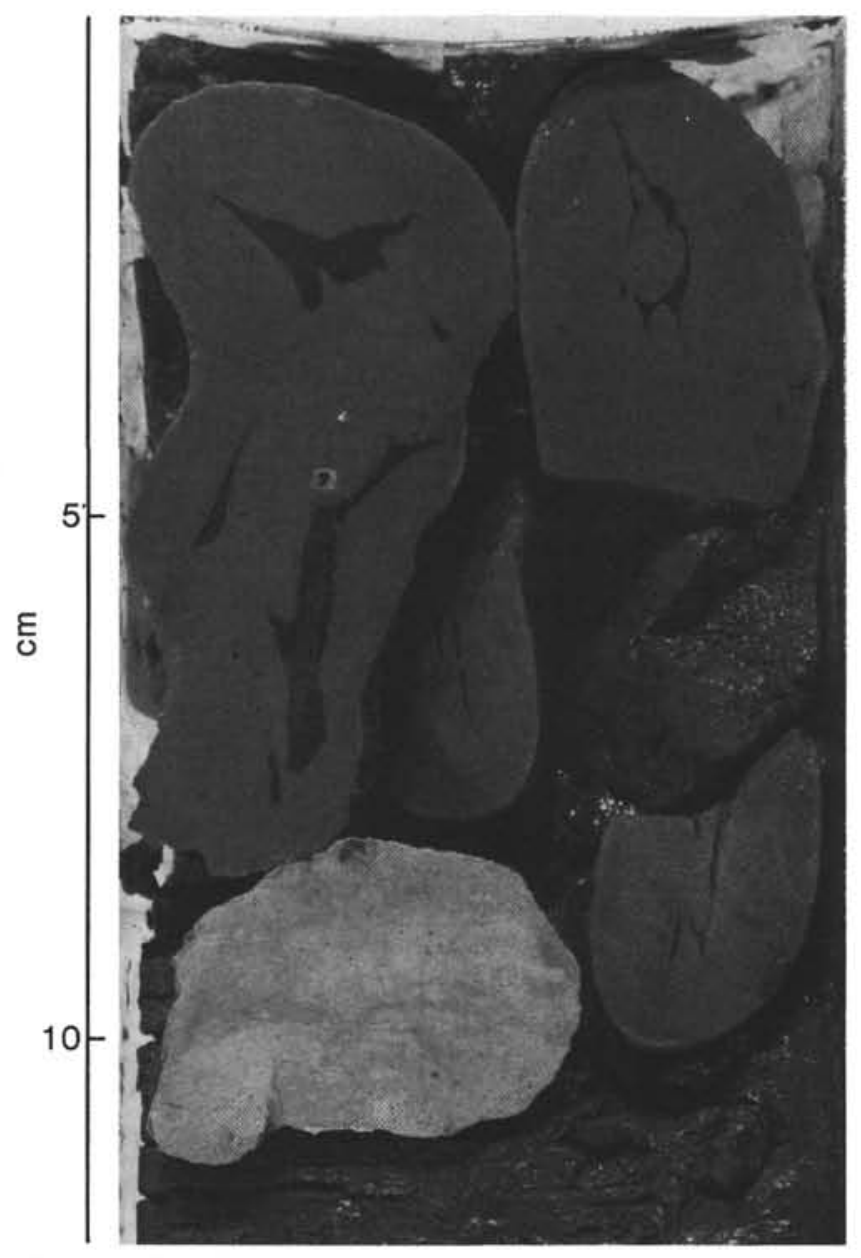

Figure 10. Sample 584-9-1, 0-11 cm. Nodules recovered at the top of this core are probably reworked from higher in the hole.

\section{Accumulation Rates and Authigenic Carbonates}

Except for diatoms, other microfossils are rare and poorly preserved at Site 584 . The diatom biostratigraphy of Site 584 corresponds to that of Sites 438 and 439 (Niitsuma and Akiba, this volume), located about $70 \mathrm{~km}$ to the northwest. Rates of accumulation estimated from selected datum levels range from a high of 200 to $70 \mathrm{~m} /$ Ma for the early Pliocene and latest Miocene, to a low of $20 \mathrm{~m} / \mathrm{Ma}$ for the early to late Miocene through late to middle Miocene. Paleomagnetic measurements render corresponding rates: $120 \mathrm{~m} / \mathrm{Ma}$ after $7.7 \mathrm{Ma}$ and 50 $\mathrm{m} / \mathrm{Ma}$ before $7.7 \mathrm{Ma}$.

The Pleistocene was a time of slow sediment accumulation at Sites 438, 439, and 584. The hiatuses at 6 and $13 \mathrm{Ma}$ at Site 438 (fig. 12 of von Huene et al., 1980) are present at Site 584, but not as noticeable gaps in the lithologic record (see fig. 5 of Niitsuma and Akiba, this volume). These breaks are placed at $590 \mathrm{~m}$ (Core 584-62) and $870 \mathrm{~m}$ (Core 584-91). Nodules of authigenic carbonate (Fig. 10) are concentrated between 0 and $100 \mathrm{~m}$ (Cores 584-2, 584-9), near $600 \mathrm{~m}$ (Core 584-63), and below $850 \mathrm{~m}$ sub-bottom (Cores 584-90, 584-92), positions that closely correspond to intervals of slow sediment accumulation (Site 584 chapter, this volume). Most nodules contain only one carbonate mineral and their com-

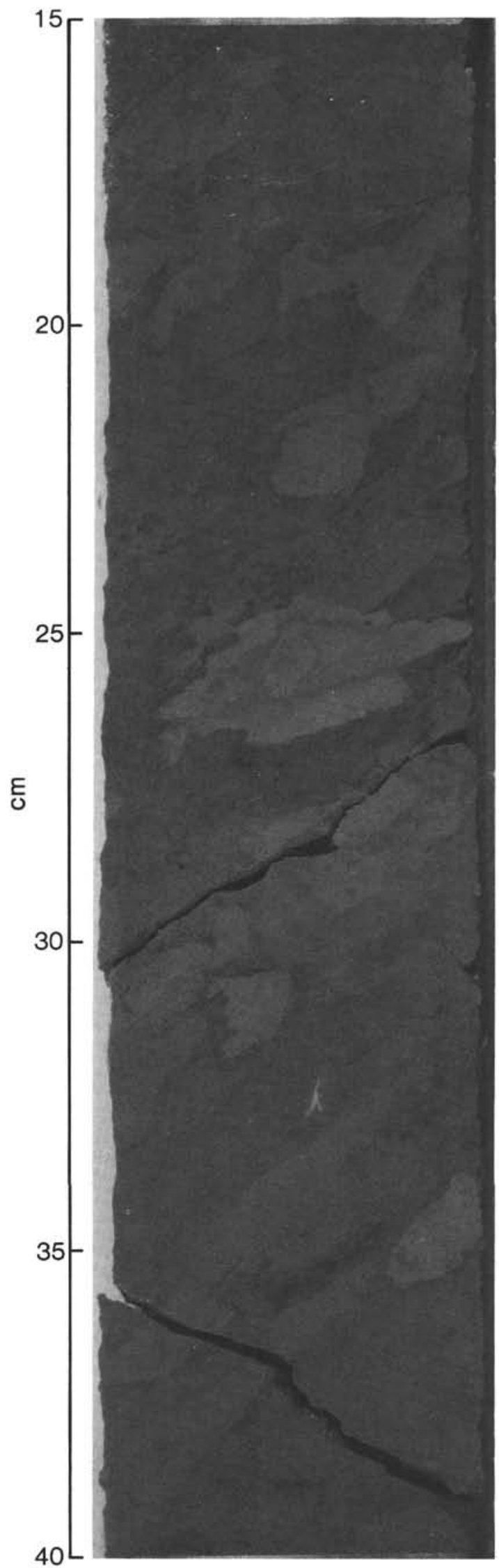

Figure 11. Core 584-52. Altered and offset Planolites and Zoophycos traces in Core 584-52. 


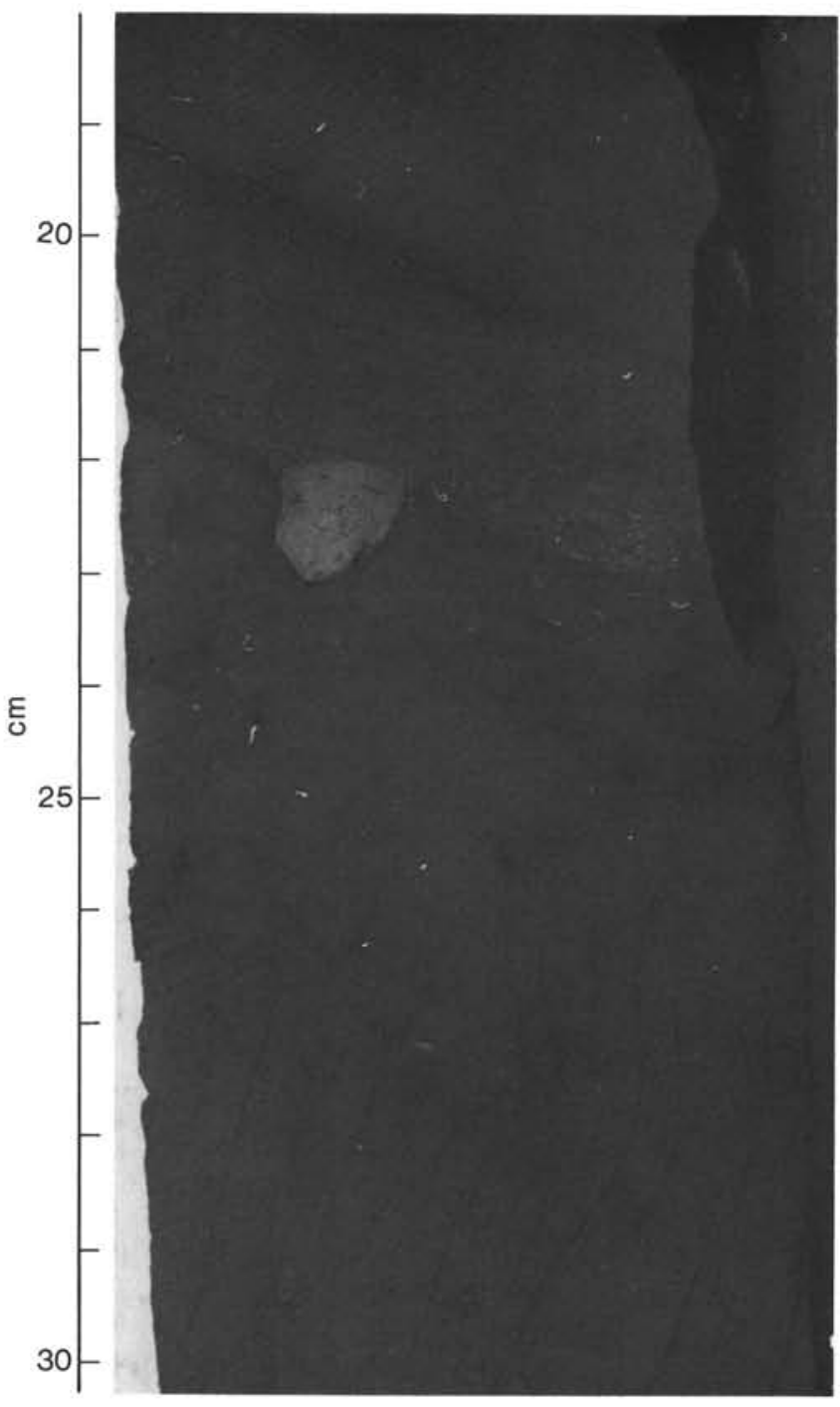

Figure 12. Section 584-95-1. Dewatering veinlets.

position varies systematically downhole (Matsumoto et al., this volume): first calcian dolomite $(0-20 \mathrm{~m})$, then magnesian calcite (20-250 m), ferroan calcite $(250-530 \mathrm{~m})$, ferroan dolomite (530-590 m), and finally siderite (590$940 \mathrm{~m})$.

\section{Local Stratigraphy and Mud Turbidites (Holes 584A and 584B)}

Only agglutinated foraminifers are represented in the assemblages recovered from Site 584 (Lagoe, this volume). The absence of calcareous benthic foraminifers indicates a deep-water environment (at least $2500 \mathrm{~m}$ ) for Site 584 for the entire time interval represented in the cores.

The basal unconformity seen in the seismic profiles proved undrillable at Hole 584-despite long drilling times the bit failed to penetrate deeper, the hole caved in, and the drill string became stuck. Air-gun-ocean-bottom-seismometer (OBS) experiments reveal the existence of island arc terrane underlying the Trench slope to within 30 to $40 \mathrm{~km}$ of the Trench axis (Suyehiro et al., this volume; Murauchi et al., 1979). This $4.8-\mathrm{km} / \mathrm{s}$ layer occurs

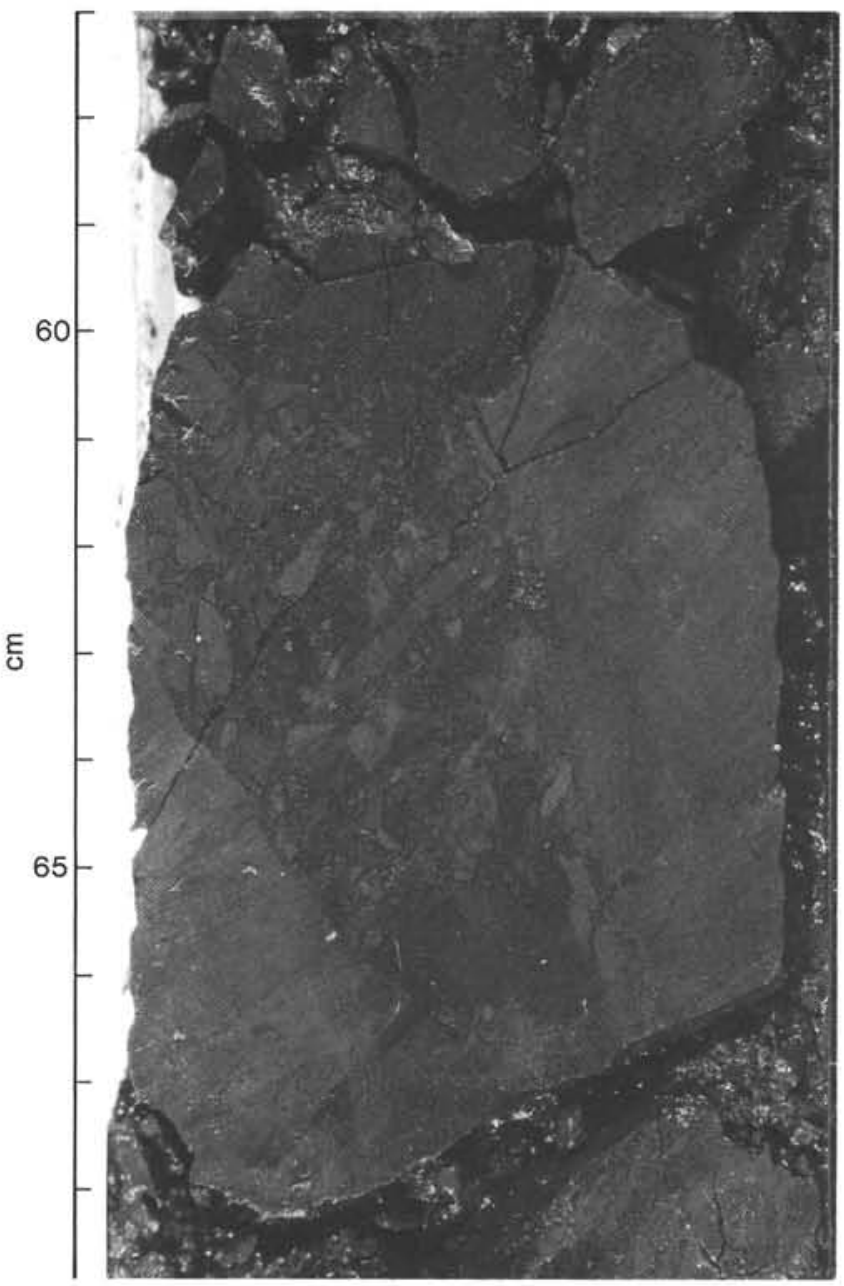

Figure 13. Core 584-71-2. Pull-apart structure.

at 1.5 to $3.2 \mathrm{~km}$ sub-bottom, deeper than the horizon that stopped drilling at Site 584. If either horizon is the surface of the Oyashio landmass, it had already subsided to bathyal depths by the earliest middle Miocene. Because this horizon was the primary objective of drilling at Site 584, Holes 584A and 584B were offset to the landward and to the seaward side of Hole 584, respectively. Both holes were spot cored and less than $27 \mathrm{~m}$ of sediment recovered (Table 1). Because coring was discontinuous, the position of the wash core in the drilled section is uncertain (by DSDP convention wash cores have the prefix " $\mathrm{H}$ ").

Mud turbidites are well preserved in Section 584A-1-1 (602.2 $\mathrm{m}$ to $611.8 \mathrm{~m}$ sub-bottom) and in the wash core taken immediately below it (Core 584A-H2, $611.8 \mathrm{~m}$ subbottom). Counterparts of these features occur in Lithologic Subunit $4 \mathrm{a}$ of Hole 584, but were first noticed at Hole 584A because of their very thin, fine sand and silt basal layers (Fig. 14). Those basal layers are much less developed at Hole 584 (Site 584 chapter, this volume). In both holes turbidites are grayer than the surrounding olive gray matrix and grade upward into Chondrites-burrowed mudstone similar to that described for Site 582 . Laminations are preserved in the mud between the basal layers and the upper bioturbated portion of each cycle. 


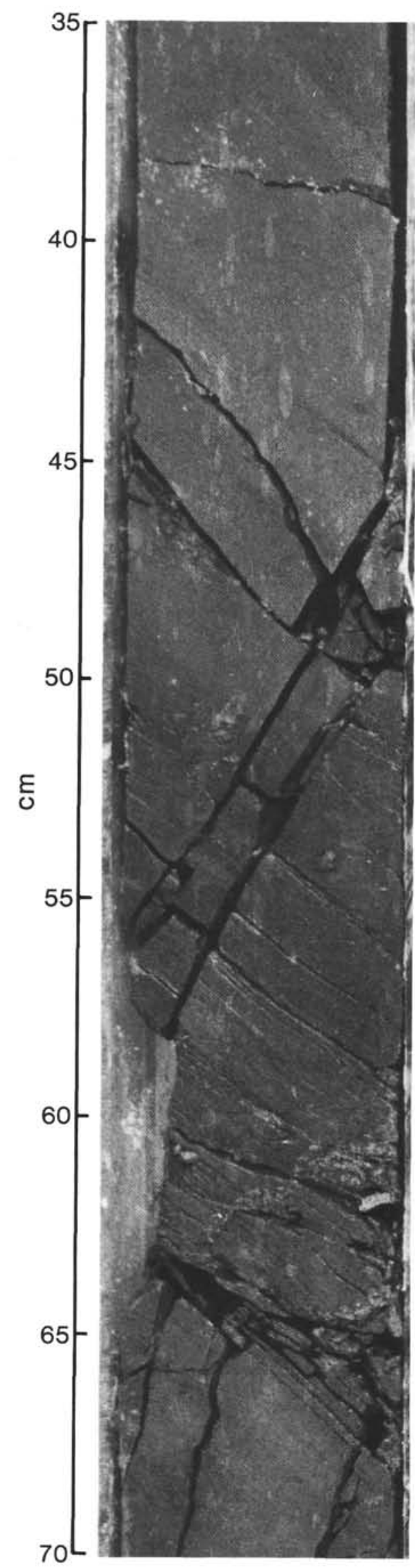

Figure 14. Section 584-1-1. Mud turbidite.
Drilling at Holes 584A and 584B also terminated at $\sim 940 \mathrm{~m}$ sub-bottom (Fig. 9); when drilling rates abruptly decreased, the holes caved, and the drill string became stuck. Although the deep objective was not sampled, the three holes drilled at Site 584 provide new insights into sub-bottom structure. Biostratigraphic datum levels and corresponding sedimentary lithologies are found at 500 and $700 \mathrm{~m}$ sub-bottom in all three holes drilled at Site 584. These horizons are correlative despite the fact that bedding in the lower portion of Hole 584 dips steeply seaward. Because seaward dips range between 20 and $70^{\circ}$ at each of the three holes and lithologic horizons remain at a uniform sub-bottom level, vertical offset must be taken up along faults in the absence of folding. Because reflectors are subparallel and horizontal (Fig. 2), such a fault system must consist of a network of offsets, each with only a small amount of displacement; the scale of the fault system must be too small to be recorded in the reflection profiles. One reconstruction employs a series of landward-dipping, listric normal faults (Karig et al., 1983). Alternatively, gravitational sliding of an extensive sedimentary accumulation (after fig. 20 of Moore and Biju-Duval, 1984) could produce a similar configuration.

\section{CONCLUSIONS}

The results from Nankai Trough drilling are inconclusive, primarily because drilling at the intended pair of holes was not completed: Site 582 was rotary cored to a considerable depth (749.4 m), and overall recovery was adequate, but no hydraulic piston cores were taken at this site (Table 1); Site 583 was hydraulic piston cored at four different locations, and overall recovery was excellent, but rotary coring reached only shallow depths at this site. Hole $583 \mathrm{~F}$ was logged continuously for almost $200 \mathrm{~m}$, but no well logs were run at Site 582 .

As expected, drilling has shown that the Nankai Trough is thickly sedimented with dark olive gray hemipelagic mud punctuated by Chondrites-turbidite intervals. Underlying muds from the Shikoku Basin are similar in color but lack the Chondrites-turbidite beds. At Site 583 the lowermost slope is blanketed by a sedimentary facies similar to the hemipelagic mud and turbidites of the Nankai Trough. Regional correlation of lithologies with Leg 31 sites is problematic due as much to poor core recovery and lack of distinctive lithologic markers as to spot coring at Site 298. Unexpected were the authigenic carbonate aggregates, the seaward-dipping and finely graded sequence of turbidites recovered in the HPC cores, the long transport distances, and the low concentrations of gas on the slope. Drilling recovered sands in both trough and slope settings, and their heavy mineral suites are compatible with a source region hundreds of kilometers to the northeast in the Tokai Basin.

Leg 87A drilling in the Nankai region leaves open the possibility of some rewarding future voyages. Site 582 should be logged and piston cored for a comparison with Site 583; Site 583 should be rotary cored to a subbottom depth at least commensurate with that reached at Site 582. The chances for successful drilling are good because, unlike conditions on other active margins, the 
holes drilled in the Nankai slope are relatively stable and the gas content is low. Weather is a major consideration, and efforts of both Leg 56 and Leg 87 were hampered by typhoons-the recollection of the view of the eye of typhoon Bess remains with the entire Leg 87A crew.

A long history of accumulation and offset of diatomaceous hemipelagic mud is recorded in the Miocene and younger sediments accumulated on the deep-sea terrace east of Honshu. Reflectors displayed in the seismic sections across the Japan forearc represent continuous strata only in a broadly averaged sense. The $940 \mathrm{~m}$ of olive gray mud drilled at Site 584 is disposed for the most part in seaward-dipping beds. This bedding attitude is not represented in the seismic profiles, and correlation of lithologies between the three holes drilled at Site 584 indicates their relatively subhorizontal disposition. Reconciliation of the bedding dip with flat-lying reflectors requires the presence of vertical offsets beyond the resolution of multichannel seismic methods. Although the nature of the fault system required to produce these offsets is speculative, the features preserved indicate that extension has prevailed in the Miocene and Pliocene, followed by shortening perpendicular to the Trench axis in the late Pliocene. The microfossil assemblages sampled at Site 584 place this portion of the deep-sea terrace at bathyal depths by the late Miocene. The combination of evidence argues for subsidence and extension of the forearc as a response to tectonic erosion of the Japanese island arc in its interaction with the subducting Pacific lithospheric plate.

\section{ACKNOWLEDGMENTS}

Ralph Moberly, Dan Karig, Hideo Kagami and E. Whalen reviewed various revisions of this summary. Thanks also to Susan Orlofsky, who edited the manuscript. It is Hawaii Institute of Geophysics Contribution No. 1636.

\section{REFERENCES}

Aoki, Y., Tamano, T., and Kato, S., 1982. Detailed structure of the Nankai Trough from migrated seismic sections. In Watkins, J. S., and Drake, C. L. (Eds.), Studies in Continental Margin Geology: Tulsa (Am. Assoc. Petrol. Geol. Mem.), 34:309-322.

Arthur, M. A., von Huene, R., and Adelseck, C. G., Jr., 1980. Sedimentary evolution of the Japan forearc region off northern Honshu, Legs 56 and 57, Deep Sea Drilling Project. In Scientific Party, Init. Repts. DSDP, 56, 57, Pt. 1: Washingtor (U.S. Govt. Printing Office), 521-568.

Aubouin, J., and Blanchet, R., 1981. Subduction and tectonics. Discussion on the results of the IPOD program in active margins. Oceanol. Acta, 4(Supplement):283-294.

Aubouin, J., Stephan, J.-F., Renard, V., Roump, J., and Lonsdale, P., 1982. A Seabeam survey of the Leg 67 area (Middle America Trench off Guatemala). In Aubouin, J., von Huene, R., and shipboard scientists, Init. Repts. DSDP, 67: Washington (U.S. Govt. Printing Office), 733-738.

Aubouin, J., von Huene, R., and Shipboard Scientists, 1982a. Init. Repts. DSDP, 67: Washington (U.S. Govt. Printing Office).

1982b. Leg 84 of the Deep Sea Drilling Project-subduction without accretion: Middle America Trench off Guatemala. $\mathrm{Na}$ ture, 297:458-460.

Belderson, R. H., Kenyon, N. H., and Stride, A. H., 1984. Morphology and structural trends of the Barbados Ridge complex in the vicinity of Deep Sea Drilling Project Sites 541, 542, and 543 as revealed by GLORIA long range sidescan sonar. In Biju-Duval, B., Moore, J. C., Init. Repts. DSDP, 78A: Washington (U.S. Govt. Printing Office), 79-81.
Berger, W. H., Adelseck, C. G., Jr., and Mayer, L. A., 1976. Dissolution of carbonate in surface sediments of the Pacific Ocean. $J$. Geophys. Res, 81:2617-2627.

Berger, W. H., and Winterer, E. L., 1974. Plate stratigraphy and the fluctuating carbonate line. In Hsü, K. J., and Jenkyns, H. C. (Eds.), Pelagic Sediments on Land and under the Sea: Oxford (Blackwell Sci. Pub.), pp. 11-48.

Bray, C. J., and Karig, D. E., 1985. Porosity of sediments in accretionary prisms and some implications for dewatering processes. J. Geophys. Res., 90:768-778.

Connolly, J., and Ewing, M., 1967. Sedimentation in the Puerto Rico Trench. J. Sed. Petrol., 37:44-59.

Coulbourn, W. T., 1981. Tectonics of the Nazca Plate and the continental margin of western South America, $18^{\circ} \mathrm{S}$ to $23^{\circ} \mathrm{S}$. In Kulm, L. D., Dymond, J., Dasch, E. J., and Hussong, D. M. (Eds.), Nazca Plate, Crustal Formation and Andean Convergence: Ann Arbor (Geol. Soc. Am. Mem. 154), pp. 587-618.

Coulbourn, W. T., Hesse, R., Azéma, J., and Shiki, T., 1982. A summary of sedimentology of Deep Sea Drilling Project Leg 67 sites: the Middle America Trench and slope off Guatemala-an active margin transect. In Aubouin, J., von Huene, R., and shipboard scientists, Init. Repts. DSDP, 67: Washington (U.S. Govt. Printing Office), 759-774.

Cowan, D. S., 1982. Origin of "vein structure" in slope sediments on the Middle America Trench off Guatemala. In Aubouin, J., von Huene, R., and shipboard scientists, Init. Repts. DSDP, 67: Washington (U.S. Govt. Printing Office), 645-650.

Damuth, J. E., 1980. Quaternary sedimentation processes in the South China basin as revealed by echo-character mapping and pistoncore studies. In Hayes, D. E. (Ed.), The Tectonic and Geologic Evolution of Southeast Asian Seas and Islands: Washington (Am. Geophys. Union), pp. 105-125.

Fitch, T. J., and Scholz, C. H., 1971. Mechanism of underthrusting in southwest Japan: a model of convergent plate interactions. J. Geophys. Res., 76:7260-7292.

Fontas, P., LeQuellec, P., Mascle, A., Renard, V., Tardy, M., and Biju-Duval, B., 1984. Multibeam bathymetric survey of the Leg 78A drilling area and comparison with the southern part of the Barbados Ridge deformation front. In Biju-Duval, B., Moore, J. C., and shipboard scientists, Init. Repts. DSDP, 78A: Washington (U.S. Govt. Printing Office), 63-78.

Hamilton, W., 1969. Mesozoic California and the underflow of Pacific mantle. Geol. Soc. Am. Bull., 80:2409-2430.

Hilde, T. W. C., Wageman, J. M., and Hammond, W. T., 1968. The structure of Tosa Terrace and Nankai Trough off southeastern Japan. Deep-Sea Res., 16:67-75.

Hussong, D. M., Uyeda, S., and shipboard scientists, 1982a. Init. Repts. DSDP, 60: Washington (U.S. Govt. Printing Office).

Hussong, D. M., Uyeda, S., Knapp, R., Ellis, H., Kling, S., and Natland, J., 1982b. Deep Sea Drilling Project Leg 60: Cruise objectives, principal results, and explanatory notes. In Hussong, D. M., Uyeda, S., and shipboard scientists, Init. Repts. DSDP, 60: Washington (U.S. Govt. Printing Office), 3-30.

Iijima, A., and Kagami, H., 1961. Cenozoic tectonic development of the continental slope, northeast of Japan. J. Geol. Soc. Japan, 67: 561-567. (In Japanese)

Ingle, J. C., Jr., Karig, D. E., and shipboard scientists, 1975. Site 297 and Site 298. In Karig, D. E., Ingle, J. C., Jr., and shipboard scientists, Init. Repts. DSDP, 31: Washington (U.S. Govt. Printing Office), 275-316 and 317-332.

Ishiwada, Y., and Ogawa, K., 1976. Petroleum geology of offshore areas around the Japanese Islands UN-ESCAP, CCOP Tech. Bull., 10:23-24.

Isshiki, N., 1977. Igneous activity and metamorphism, Neogene and Quaternary. In Tanaka, K., and Nozawa, T. (Eds.), Geology and Mineral Resources of Japan (3rd edition): Kawasaki (Geol. Surv. Japan), 373-417.

Kanamori, H., and Tsumura, K., 1971. Spatial distribution of earthquakes in the Kii Peninsula, Japan, south of the median tectonic line. Tectonophysics, 12:327-342.

Karig, D. E., Ingle, J. C., Jr., and shipboard scientists, 1975. Init. Repts. DSDP, 31: Washington (U.S. Govt. Printing Office).

Karig, D. E., Kagami, H., and shipboard scientists, 1983. Varied responses to subduction in Nankai Trough and Japan Trench forearcs. Nature, 304:148-151. 
Konda, T., 1974. Bimodal volcanism in the northeast Japan arc. J. Geol. Soc. Japan, 80(2):81-89. (In Japanese with English abstract)

Leggett, J. K., 1980. The sedimentological evolution of a Lower Paleozoic accretionary fore-arc in the Southern Uplands of Scotland. Sedimentology, 27:401-417.

Ludwig, W. J., Den, N., and Murauichi, S., 1973. Seismic reflection measurements of southwest Japan margin. J. Geophys. Res., 78: 2508-2516.

Mackinnon, T. C., 1983. Origin of the Torlesse terrane and coeval rocks, South Island, New Zealand. Geol. Soc. Am. Bull., 94:967-983.

McMillen, K. J., Enkeboll, R. H., Moore, J. C., Shipley, T. H., and Ladd, J. W., 1982. Sedimentation in different tectonic environments of the Middle America Trench, southern Mexico and Guatemala. In Leggett, J. K. (Ed.), Trench-forearc Geology: London (Geol. Soc. London Spec. Pub. 10, Blackwell Sci. Pub.), pp. 107-119.

McMillen, K. J., and Haines, T. R., 1982. Late Quaternary sediments of the southern Mexico margin. In Moore, J. C., Watkins, J. S., and shipboard scientists, Init. Repts. DSDP, 66: Washington (U.S. Govt. Printing Office), 437-443.

Moore, G. F., Billman, H. G., Hehanussa, P. E., and Karig, D. E., 1980. Sedimentology and paleobathymetry of Neogene trenchslope deposits, Nias Island, Indonesia. J. Geol., 88:161-180.

Moore, J. C., 1973. Complex deformation of Cretaceous trench deposits, southwestern Alaska. Geol. Soc. Am. Bull., 84:2005-2020.

Moore, J. C., and Biju-Duval, B., 1984. Tectonic synthesis, Deep Sea Drilling Project Leg 78A: structural evolution of offscraped and underthrust sediment, northern Barbados Ridge complex. In Moore, J. C., Biju-Duval, B., and shipboard scientists, Init. Repts. DSDP, 78A: Washington (U.S. Govt. Printing Office), 601-621.

Moore, J. C., Biju-Duval, B., and shipboard scientists, 1982. Offscraping and underthrusting of sediment at the deformation front of the Barbados Ridge. Geol. Soc. Am. Bull., 93:1065-1077.

1984. Site 541 and Site 542. In Biju-Duval, B., Moore, J. C., and shipboard scientists, Init. Repts. DSDP, 78A: Washington (U.S. Govt. Printing Office), 107-186 and 187-225.

Murauchi, S., Asanuma, T., Kinoshita, H., Nakatani, H., Mitamura, M., Sakai, M., Tokumaru, M., and Hayashi, K., 1979. Sediments and structure of the subduction zone off northeast Japan. EOS, 60:315. (Abstract)

Nasu, N., et al., 1979. Multi-channel Seismic Reflection Data Across the Japan Trench. IPOD-Japan Basic Data Series, 3: Tokyo (Ocean Research Institute).

1982. Multi-channel Seismic Reflection Data Across Nankai Trough. IPOD-Japan Basic Data Series, 4: Tokyo (Ocean Research Institute).

Ogawa, Y. and Miyata, Y., 1985. Vein structure and its deformational history in the sedimentary rocks of the Middle America Trench slope off Guatemala, Deep Sea Drilling Project Leg 84. In von Huene, R., Aubouin, J., and shipboard scientists, Init. Repts. DSDP, 84: Washington (U.S. Govt. Printing Office), 811-829.

Renard, V., Aubouin, J., Lonsdale, P., and Stephan, J.-F., 1980. Premiers résultats d'une étude de la fosse d'Amerique centrale au soundeur multifaisceaux (Seabeam). C.R. Acad. Sci. Ser. D, 291:137142.

Ritger, S. D., 1985. Origin of vein structures in the slope deposits of modern accretionary prisms. Geology, 13:437-439.

Sato, T., 1973. Several considerations of the deep sea plains. Mar. Sci. Monthly, 5(10):55-59. (In Japanese).

Saunders, J. B., Bernoulli, D., Mueller-Merz, E., Oberhansli, H., Perch-Nielsen, K., Riedel, W. R., Sanfillippo, A., and Torrini, R., Jr., 1984. Stratigraphy of the late middle Eocene to early Oligocene in the Bath Cliff Section, Barbados, West Indies. Micropaleontology, 30:390-425.

Scholl, D. W., and Marlow, M. S., 1974. Global tectonics and sediments of modern and ancient trenches; some different interpretations. In Kahle, C. F. (Ed.), Plate Tectonics Assessments and Reassessments: Tulsa (Am. Assoc. Pet. Geol., Mem. 23), 255-272.

Scholl, D. W., Marlow, M. S., and Cooper, A. K., 1977. Sediment subduction and offscraping at Pacific margins. In Talwani, M., and Pitman, W. C., III (Eds.), Island-Arcs, Deep Sea Trenches, and Back-arc Basins: Washington (Am. Geophys. Union, Maurice Ewing Ser. 1), pp. 199-210.

Scientific Party, 1980. Init. Repts. DSDP, 56, 57, Pts. 1 and 2: Washington (U.S. Govt. Printing Office).

Seely, D. R., Vail, P. R., and Walton, G. G., 1974. Trench-slope model. In Burk, C. A., and Drake, C. L. (Eds.), The Geology of Continental Margins: New York (Springer-Verlag), pp. 249-260.

Seiders, V. M., 1983. Correlation and provenance of upper Mesozoic chert-rich conglomerates of California. Geol. Soc. Am. Bull., 94: 875-888.

Seno, T., 1977. The instantaneous rotation vector of the Philippine Sea plate relative to the Eurasian plate. Tectonophysics, 42:209226.

Shipley, T. H., Houston, M. H., Buffler, R. T., Shaub, F. J., McMillen, K. J., Ladd, J. W., and Worzel, J. L., 1979. Seismic evidence for widespread possible gas hydrate horizons on continental slopes and rises. Am. Assoc. Petrol. Geol. Bull., 63:2204-2213.

Speed, R. C., 1981. Geology of Barbados: implications for an accretionary origin. Oceanol. Acta, 4(Supplement):259-265.

Stride, A. H., Belderson, R. H., and Kenyon, N. H., 1982. Structural grain, mud volcanoes, and other features on the Barbados Ridge complex revealed by GLORIA Long-range side-scan sonar. Mar. Geol., 49:187-196.

Suess, E., Balzar, W., Hesse, K-F., Mueller, P. J., Ungerer, C. A., and Wefer, G., 1982. Calcium carbonate hexahydrate from organic-rich sediments of the Antarctic shelf: precursors of glendonites. Science, 216:1128-1131.

Sugimura, A., 1972. Plate boundaries around Japan. Kagaku, 42: 192-202. (In Japanese)

Taira, A., 1981. The Shimanto Belt of southwest Japan and arc-trench sedimentary tectonics. Recent Progress of Natural Sciences in Japan, 6:147-162.

Taira, A., Okada, H., Whitaker, J. H. McD., and Smith, A. J., 1982. The Shimanto, Belt of Japan: Cretaceous-lower Miocene activemargin sedimentation. In Leggett, J. K. (Ed.), Trench-Forearc Geology: Oxford (Blackwell Sci. Pub.), pp. 5-26.

Talwani, M., and Langseth, M., 1981. Ocean crustal dynamics. Science, 213:22-31.

Uyeda, S., 1974. Northwest Pacific trench margins. In Burk, C. A., and Drake, C. L. (Eds.), The Geology of Continental Margins: New York (Springer-Verlag), pp. 473-491.

von Huene, R., Langseth, M., Nasu, N., and Okada, H., 1982. A summary of Cenozoic tectonic history along the IPOD Japan Trench transect. Geol. Soc. Am. Bull., 93:829-846.

von Huene, R., Nasu, N., and shipboard scientists, 1980. Site 438 and Site 439. In Scientific Party, Init. Repts. DSDP, 56, 57, Pt. 1: Washington (U.S. Govt. Printing Office), 23-191.

Westbrook, G. K., and Smith, M. J., 1983. Long décollements and mud volcanoes: evidence from the Barbados Ridge Complex for the role of high pore-fluid pressure in the development of an accretionary complex. Geology, 11:279-283.

Westbrook, G. K., Smith, M. J., Peacock, J. H., and Poulter, M. J., 1982. Extensive underthrusting of undeformed sediment beneath the accretionary complex of the Lesser Antilles subduction zone. Nature, 300:625-628.

White, R. S., and Louden, K. E., 1982. The Makran convergent margin: structure of a thickly sedimented convergent plate boundary. In Watkins, J. S., and Drake, C. L. (Eds.), Studies in Continental Margin Geology: Tulsa (Am. Assoc. Petrol. Geol., Mem. 34), pp. 499-518.

Yoshii, T., Ludwig, W. J., Den, N., Murauchi, S., Ewing, M., Hotta, H., Buhl, P., Asanuma, T., and Sakajiri, N., 1973. Structure of southwest Japan margin off Shikoku. J. Geophys. Res., 78:25172525.

Zen, E., 1959. Mineralogy and petrology of marine bottom sediment samples off the coast of Peru and Chile. J. Sed. Petrol., 29: 513-539.

Date of Initial Receipt: 16 July 1985

Date of Acceptance: 21 August 1985 